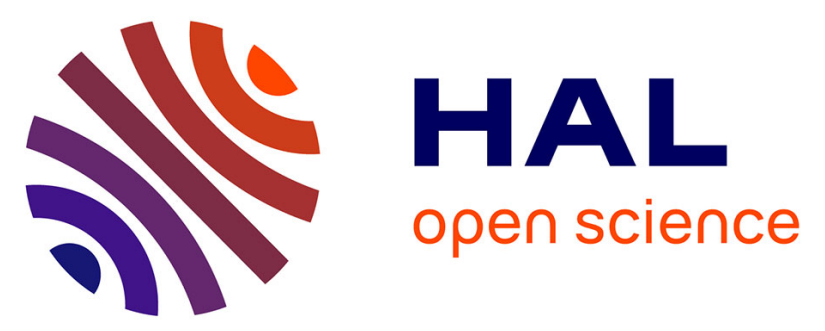

\title{
Exploring the dew retting feasibility of hemp in very contrasting European environments: Influence on the tensile mechanical properties of fibres and composites
}

Samuel Réquilé, Brahim Mazian, Marie Grégoire, Salvatore Musio, Maxime Gautreau, Lucile Nuez, Arnaud Day, P. Thiébeau, Florian Philippe, Brigitte Chabbert, et al.

\section{To cite this version:}

Samuel Réquilé, Brahim Mazian, Marie Grégoire, Salvatore Musio, Maxime Gautreau, et al.. Exploring the dew retting feasibility of hemp in very contrasting European environments: Influence on the tensile mechanical properties of fibres and composites. Industrial Crops and Products, 2021, 164, pp.113337. 10.1016/j.indcrop.2021.113337 . hal-03154888

\section{HAL Id: hal-03154888 \\ https://hal.mines-ales.fr/hal-03154888}

Submitted on 2 Mar 2021

HAL is a multi-disciplinary open access archive for the deposit and dissemination of scientific research documents, whether they are published or not. The documents may come from teaching and research institutions in France or abroad, or from public or private research centers.
L'archive ouverte pluridisciplinaire HAL, est destinée au dépôt et à la diffusion de documents scientifiques de niveau recherche, publiés ou non, émanant des établissements d'enseignement et de recherche français ou étrangers, des laboratoires publics ou privés.

\section{(1) (1) $\$$}

Distributed under a Creative Commons Attribution - NonCommercial - NoDerivatives 44.0 


\title{
Exploring the dew retting feasibility of hemp in very contrasting European environments: Influence on the tensile mechanical properties of fibres and composites
}

\author{
Samuel Réquilé ${ }^{\mathrm{a}}$, Brahim Mazian ${ }^{\mathrm{b}, \mathrm{c}}$, Marie Grégoire ${ }^{\mathrm{d}}$, Salvatore Musio ${ }^{\mathrm{e}}$, Maxime Gautreau ${ }^{\mathrm{f}}$, \\ Lucile Nuez $^{\mathrm{a}}$, Arnaud Day ${ }^{\mathrm{g}}$, ${ }^{\text {, Pascal Thiébeau }}{ }^{\mathrm{i}}$, Florian Philippe ${ }^{\mathrm{i}}$, Brigitte Chabbert ${ }^{\mathrm{i}}$, \\ Anne Chamussy $^{\mathrm{j}}$, Darshil U. Shah ${ }^{\mathrm{k}}$, Johnny Beaugrand ${ }^{\mathrm{f}}$, Vincent Placet ${ }^{1}$, \\ Jean-Charles Benezet ${ }^{\mathrm{b}}$, Antoine le Duigou ${ }^{\mathrm{a}}$, Mahadev Bar ${ }^{\mathrm{d}}$, Luc Malhautier ${ }^{\mathrm{c}}$, \\ Emmanuel De Luycker ${ }^{\mathrm{d}}$, Stefano Amaducci ${ }^{\mathrm{e}}$, Christophe Baley ${ }^{\mathrm{a}}$, Anne Bergeret ${ }^{\mathrm{b}}$, \\ Alain Bourmaud $^{\mathrm{a}}$, Pierre Ouagne ${ }^{\mathrm{d}, *}$ \\ ${ }^{a}$ Univ. Bretagne Sud, UMR CNRS 6027, IRDL, F-56100 Lorient, France \\ ${ }^{\mathrm{b}}$ Polymers Composites and Hybrids (PCH), IMT Mines Ales, 6 Avenue de Clavieres, 30319, Ales Cedex, France \\ ${ }^{\mathrm{c}}$ Laboratoire des Sciences des Risques (LSR), IMT Mines Ales, 6 Avenue de Clavieres, 30319, Ales Cedex, France \\ ${ }^{\mathrm{d}}$ Laboratoire Génie de Production, LGP, Université de Toulouse, INP-ENIT, Tarbes, France \\ e Department of Sustainable Crop Production, Università Cattolica del Sacro Cuore, Piacenza, Italy \\ ${ }^{\mathrm{f}}$ UR1268 Biopolymères Interactions Assemblages, INRAE, Nantes, France \\ ${ }^{g}$ Fibres Recherche Développement, Technopole de l'Aube en Champagne, Hotel de Bureaux 2 - 2 rue Gustave Eiffel, CS 90601-10901 Troyes Cedex 9, France \\ ${ }^{\mathrm{h}}$ CNRS, UMR8576, UGSF- Unité de Glycobiologie Structurale et Fonctionnelle, Unité de Lille, 59000 Lille, France \\ ${ }^{\mathrm{i}}$ Université de Reims Champagne Ardenne, INRAE, FARE, UMR A 614, 51097 Reims, France \\ ${ }^{\mathrm{j}}$ La Chanvrière, Rue du Général de Gaulle, CS 20602, 10200, Bar-sur-Aube, France \\ ${ }^{\mathrm{k}}$ Centre for Natural Material Innovation, Dept. of Architecture, University of Cambridge, Cambridge CB2 1PX, United Kingdom \\ ${ }^{1}$ FEMTO-ST Institute, UFC/CNRS/ENSMM/UTBM, Université Bourgogne Franche-Comté, Besançon, France
}

\section{A B S T R A C T}

Retting of fibrous plants such as flax is an essential step in the extraction of fibre bundles and their trans-formation into textiles and reinforcement fabrics for use in garments and composites. Dew-retting is traditionally performed from Northwest France to the Netherlands, as the climate is highly favourable for this process. Hemp is a plant that can be grown almost all over Europe with a low environmental impact. A retting step is also required to facilitate the separation of the hemp fibres before their transformation into textiles for garments or for 1D to 3D reinforcement composites, which requires thoroughly separated fibres. Dew-retting is currently used in flax production zones. The present work demonstrates that dew retting can be conducted under different climates on different soils, from dry Mediterranean environments up to the cooler regions of eastern France. If the ternary combination of moisture, temperature and solar radiation is appropriate, field retting (dew-retting) can be as short as about three weeks. In less favourable conditions, such as in dryer areas or when retting is performed late in the season after seed maturity (cooler temperatures), it lasts longer, but it can reach suitable levels. When conducted with care and with proper monitoring of the retting level, the dew-retting process does impact neither the tensile properties of elementary hemp fibres (by degrading crystalline cellulose I) nor the tensile properties of unidirectional and injected composite materials. Consequently, if extracted with a suitable process such as scutching and hackling, fibres suitable for load-bearing composites can be produced from dew-retted hemp stems produced in a wide range of climates and locations, therefore not limited to the conventional "dew retting zone" of flax production areas.

\footnotetext{
* Corresponding author.

E-mail address: pierre.ouagne@enit.fr (P. Ouagne).
} 


\section{Introduction}

Among the fibre plants used as composite reinforcements, hemp could play a significant role in the next decade, especially in Europe, mainly because of the good specific properties of its fibres, the limited environmental impact of its cultivation and also the cost and availability of these fibres (A. Bourmaud et al., 2018). Their high aspect ratio offers true reinforcement potential for composites, in contrast to fine wood flour, commonly used as a filler. The latter is available at a similar cost but is notably less effective as reinforcement (Dickson et al., 2014). The appearance on the market of industrial composite parts reinforced by hemp fibres underlines this growth forecast.

Hemp fibres have a structural and parietal organisation comparable to that of flax fibres, in terms of biochemical composition, cellulose crystallinity or ultrastructural characteristics such as multi-layer wall organisation or microfibrillar angle (MFA) (Bourmaud et al., 2013b; Marrot et al., 2013). However, at the industrial scale, they exhibit lower mechanical properties which can be attributed to the differences in scattering of some of their morphological and ultrastructural properties (Masto et al., 2019), as well as to the fibre extraction method, generally carried out by hammer mills (Bag et al., 2012). However, despite a higher variability, Musio et al. (2018) have shown that it is possible to obtain hemp fibres with similar mechanical performances to those of flax fibres using the scutching process. This opens possibilities for new applications such as load-bearing composites for these fibres.

In order to enhance bio-composite performance and better implement these materials in new applications at industrial scale, various strategies have been developed to modify the bulk and surface properties of the plant fibres (Belgacem and Gandini, 2005; George and Verpoest, 1999; John and Anandjiwala, 2008; Kalia et al., 2009; Le Moigne et al., 2018). The recommended strategy is often the modification of the fibres by chemical or physical treatment. This strategy has actually been embraced for a long time (Hessler, 1946). The treatments are usually inspired by the synthetic materials industry (Kabir et al., 2012) and the environmental impact is not always considered. The strategy used here is different and aims to modify the fibres through an agricultural process before their extraction. After the period of growth, following fibre maturity and prior to harvesting the straw, the hemp plant undergoes a field-retting stage (Bennett et al., 2006) also called dew retting. In this retting step, the cortical part of the plant as well as the pectic middle lamellae binding the fibres together in a bundle undergo a partial degradation. This is caused by the action of microorganisms that develop first on the plant's surface and then penetrate into the plant tissues, before and during retting. The microorganisms release specific enzymes (mostly pectinase) that attack these binding zones (Djemiel et al., 2017; Ribeiro et al., 2015). This facilitates the mechanical extraction of the fibres in hemp or in flax (Chabbert et al., 2020).

Compared to flax, for which dew-retting starts in July in highly favourable areas situated mostly in Northern France, Belgium and Netherlands, hemp dew-retting commonly starts in mid-August or September, since fibre and seed maturity are achieved in mid-August for most early varieties. For later varieties (Futura 75, Santhica 27 and Fedora 17), the field-retting (dew-retting) period can take place in October if the climate is favourable. The goal of the retting process is to facilitate fibre extraction, while preserving the morphological and mechanical potential of the fibres. For this reason, hemp retting (water retting) was performed for a long time and traces of hemp retting have been found even at the late Holocene age, $500 \mathrm{BC}-\mathrm{AD} 1050$ in the Himalayan area (Demske et al., 2016)), whereas recent archaeological investigations in England showed that hemp retting was performed by water immersion as from the 13th century (Tuck, 2018). Field-retting, however, relies on weather conditions and the risk of an uncontrollable stage due to adverse weather conditions exists. This was pointed out for a long time without any real technical solution (Hessler, 1945). An increase in precipitation and relative humidity can lead to an increase in the moisture content in the stems and could then make their collection difficult or impossible due to rotting and heighten the risk of potential fire outbreaks during storage. Stems may also be over-retted when cellulose, the main structural component of the fibres, is enzymatically attacked and depolymerised (Placet et al., 2017) by the secretion of a second type of enzyme (cellulase). As the weather varies geographically (from one location to another) and temporally (from one year to another), a "standard" retting time cannot be set. As a consequence of all these influencing factors, under-retting or over-retting of the straws may occur. The field-retting process must therefore be monitored very carefully to determine the optimal stage and harvest time (Hessler, 1945).

Hence, questions related to the consequences of field-retting may arise with a view to developing hemp fibre biocomposite materials (Liu et al., 2017). The impacts of retting on the final performance of biocomposites are still not fully understood, although some data is available at fibre scale (Placet et al., 2017).

At the scale of the hemp plant and hemp, literature shows that significant decohesion of the stem structure occurs during retting. This has been demonstrated by both peeling and bending tests (Réquilé et al., 2018a, b), as well as through microscopic observations (Bleuze et al., 2018; Mazian et al., 2018). During these dynamics, changes in the colour of the stems occur - from yellow to dark grey - as the retting process progresses (Bleuze et al., 2018; Placet et al., 2017). The impact on the fibre properties has been reported to be significant, although contradictory conclusions have also been put forward. In terms of biochemical composition, a decrease in pectin compounds gradually occurs during retting whereas lignin is recalcitrant to enzymatic degradation (Liu et al., 2015; Mazian et al., 2018; Placet et al., 2017; Hessler, 1945; Fuller and Norman, 1946).

Accordingly, pectin is the first component targeted by the action of microorganisms, as observed in flax (Chabbert et al., 2020) and the cellulose of the fibres is doubtless preserved during the retting period (Akin et al., 2007). Conclusions in the literature differ on the evolution of mechanical performance of fibres during retting. Some authors have described an increase in the stiffness and strength of the fibres or fibre bundles during retting (Mazian et al., 2018; Réquilé et al., 2018b) while others have found the opposite effect (Liu et al., 2015; Placet et al., 2017; Hessler, 1945). Contradictory results concerning the degree of cellulose crystallinity in hemp fibre cell walls were also reported following the use of modern analytical methods (Mazian et al., 2018; Placet et al., 2017) whereas a paper based on a hardly comparable method already pointed out the question of the cellulose depolymerisation in the 1940s' (Fuller and Norman, 1946).

The contradictory results may be the result of different retting conditions (e.g. retting duration), revealing the complexity of comparing results for plants from different cultivars or having grown under different climatic conditions (Jankauskiene et al., 2015). The differences in characterisation methods (e.g. methods of tensile tests on elementary fibres or bundles) is also important.

The mechanical extraction of fibres was chosen. The method used to extract the fibres may thus impact the fibres' morphology as well as their structural and physicochemical properties. A recent demonstration of all the previous statements is presented by Vandepitte et al. (2020). The authors used flax scutching machines to extract hemp fibres, leading to significant variations in straw yield between harvest years, while variations in fibre tenacity of the hemp bundles from different genotypes were observed. They indicate that field-retted hemp fibres have a high potential for textile applications, but further work on genotype selection and process adjustments would be beneficial to optimise the fibre yield.

The impact of hemp field retting on composite performance has received little attention in literature. Regarding flax, studies have demonstrated the increase in mechanical properties of both elementary fibres and associated injection-moulded composite with increasing retting level (Martin et al., 2013). One of the main effects of retting is the individualisation of fibres. Within a composite with either pelletised (for injection-moulding) or aligned unidirectional reinforcements, fibre 
individualisation increases the fibre-matrix interface area and increases load transfer between these two constituents. It has been shown that more divided or defibrillated reinforcements significantly improve the performance of biocomposites (Coroller et al., 2013). Therefore, variations can be gradual depending on the type of composite processing (Haag et al., 2017) and also on the nature of the reinforcement fibre fraction. Mid-performance composites were manufactured with losses (hackling tows) from the hackling process of long hemp (Müssig et al., 2020).

The results proposed in this paper are from three different studies (originally disconnected) and performed quasi simultaneously in three different European locations (Eastern France, Southeast France and Northern Italy). The data and analysis proposed in the following sections are not the result of an a priori, well-designed study but a compilation of information the objective of which is to investigate if:

- Dew retting can be performed advantageously in very different environments on different soils and in climates outside of the traditional flax dew-retting zone (from Northwest France to the Netherlands)

- Dew retting of hemp impacts the tensile properties of hemp fibres and is therefore a good process to obtain fibres that are suitable for load-bearing composite material applications.

Different dew-retting, harvesting and extraction processes were used to produce fibres that were characterised at fibre scale and used to produce composite samples. The impact of different parameters, including pedoclimatic conditions, retting durations and hemp variety, on the performance of the hemp fibres and on their composites was studied. Three batches of hemp fibre were selected, each from a different variety, grown in different places and unique climates. Harvesting conditions also differ according to each location (manually or mechanically harvested, at the end of flowering or at seed maturity). The hemp stems were consequently field-retted under different weather conditions. First, the evolution of mechanical performance and degree of cellulose crystallinity of these fibres during retting was determined by tensile tests on elemental fibres and by X-ray diffraction, respectively. Then, the impact of retting on composite performance was studied. For this purpose, injection-moulded hemp-PP and unidirectional hempepoxy biocomposites were produced and mechanically characterised.

\section{Materials and methods}

An overview of the experimental work performed at the different sites is presented in Fig. 1. The detail of the different materials and methods used to obtain the presented data is described in the following Sections.

\subsection{Experimental sites}

The experiments were carried out in Italy and France. The experimentation sites were located in: Piacenza, Northern Italy (N $45.052^{\circ}$, E $9.692^{\circ}$ ), Alès, Southern France (N 44.130 ${ }^{\circ}, \mathrm{E} 4.315^{\circ}$ ) and La Croix-enChampagne (La Croix), Northern France (N 49.067 ${ }^{\circ}$, E 4.648 ${ }^{\circ}$ ).

The main agronomic characteristics of these soils were as follows: the plowed horizon of the Piacenza site was clay loam with $42 \%$ clay, $46 \%$ silt and $12 \%$ sand. The soil of the Alès site was clay-limestone with a plowed horizon composed of $30 \%$ clay, $50 \%$ silt and $19 \%$ sand. The soil texture of the $0-20 \mathrm{~cm}$ horizon in La Croix was composed of $7 \%$ clay, 8 $\%$ silt, $1 \%$ sand and $83 \%$ CaCO. Then the $22-25 \mathrm{~cm}$ horizon was a grey rendzine on gelifracted chalk (Ballif et al., 1995).

\subsection{Hemp cultivation}

Three hemp (Cannabis Sativa L.) monoecious cultivars were selected. Futura 75, Santhica 27 and Fedora 17 were sown at 120, 260 and 170 seeds $/ \mathrm{m}^{2}$ on Piacenza, Alès and La Croix respectively. These cultivars differ in precocity as full flowering is obtained with a difference of about

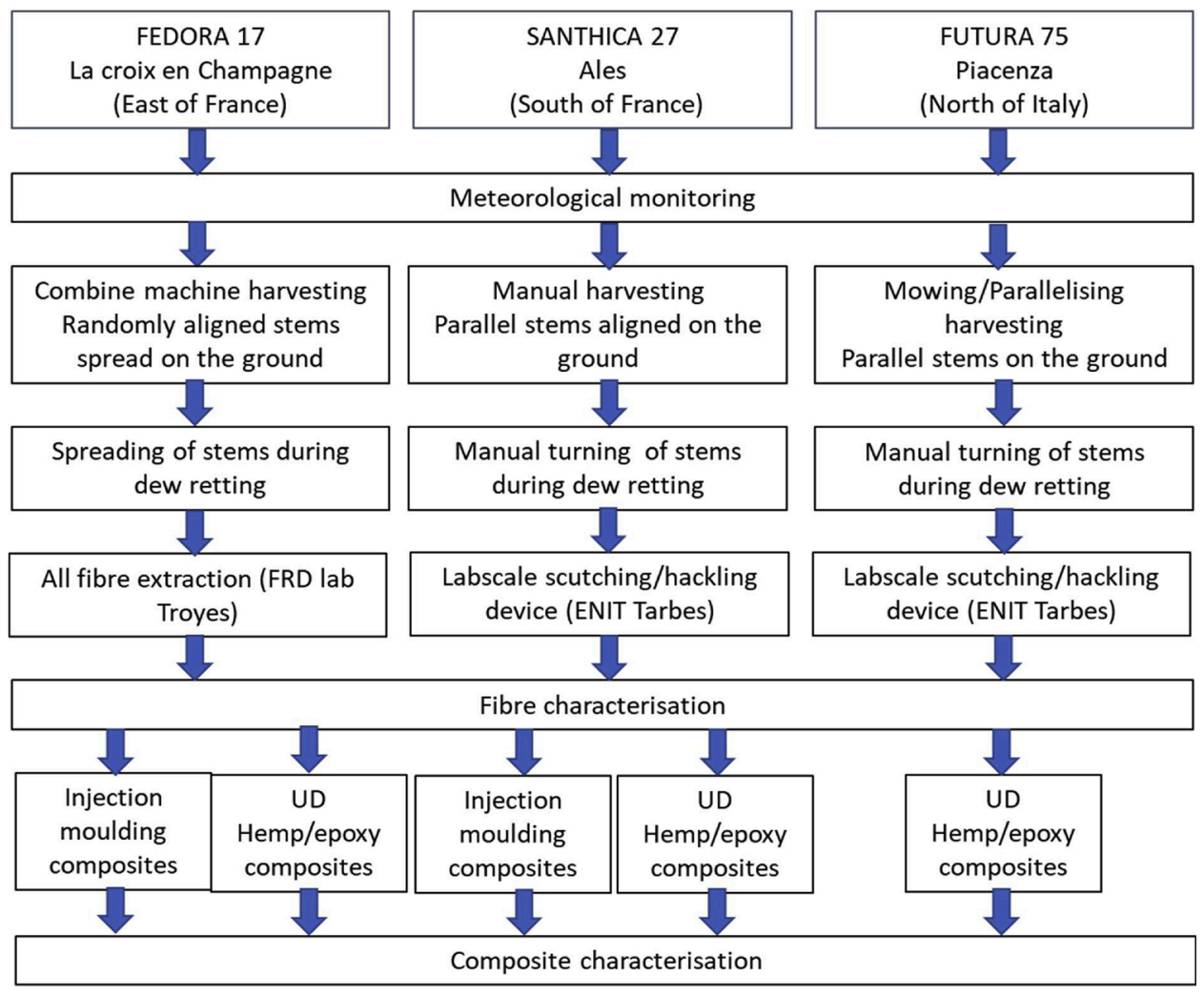

Fig. 1. Schematic representation of the experimental work. 
15 calendar days between the latest and the earliest cultivars (Futura75 $<$ Santhica27 $<$ Fedora17). The main cultivation dates, including retting are shown in Fig. 2.

The hemp stems were harvested at two growth stages: (1) manually at the end of flowering for Santhica 27 (21st August 2017) and (2) mechanically at seed maturity for Futura 75 and Fedora 17 (20th September 2016 and 29th September 2017, respectively). After each harvest period, the plants were left in the field for retting, for different time periods R1 and R2 (Fig. 2). Only 2 samplings were considered for Futura 75 (R0 and R2) and 3 for other varieties (R0, R1 and R2). The harvested plants were turned on the ground regularly to homogenise retting of the stems. A random selection of the retted stems was used for this study.

\subsection{Monitoring of climatic conditions}

For each experiment, the daily weather data were collected in the field, using a mobile station (Fig. 3). The main climatic variables collected are the average air temperature, global radiation, and rainfall. Temperature data were also reported as cumulative degree-days base $0{ }^{\circ} \mathrm{C}$ during the growth period of hemp, and as standard days during the retting periods. The standard days method is used by several agronomic models to simulate organic matter evolution in soil (Brisson et al., 2009; Mary et al., 1999). This concept transforms each measurement day into a duration expressed per day at a reference temperature and humidity, called "standard day" (SD). The commonly used temperature is $15{ }^{\circ} \mathrm{C}$. The humidity function of the method is of second order with respect to temperature and it can be neglected, as shown by Thiebeau and Recous (2017). The equation used is as follows:

$\mathrm{SD} 15=25 /\left(1+145 \times \exp \left(-0.120 \times \mathrm{T}^{\circ}\right)\right)$

where SD15 is the number of standard days at $15{ }^{\circ} \mathrm{C}$; $\mathrm{T}^{\circ}$ is the average temperature of the day, collected $2 \mathrm{~m}$ under shelter, expressed in degrees Celsius.

\subsection{Monitoring of meteorological data}

Temperature, rainfall and solar radiation were monitored from the sowing date to stem collection of the three studied hemp batches after retting. The meteorological data of the experimental sites are in agreement with the Köppen-Geiger classification (Belda et al., 2014), which is based on average multi-year (30 years) climatic conditions. Thus the climate of the experimental sites is different and can be classified as 1) a warm subtropical climate with no dry season (mean temperature: 13.2 ${ }^{\circ} \mathrm{C}$; cumulative rainfall: $829 \mathrm{~mm}$ ) in Piacenza, 2) a hot Mediterranean climate with a dry summer (mean temperature: $14.8{ }^{\circ} \mathrm{C}$; cumulative rainfall: $698 \mathrm{~mm}$ ) in Alès, 3) a warm oceanic climate, without a dry season (mean temperature: $10.5^{\circ} \mathrm{C}$; cumulative rainfall: $617 \mathrm{~mm}$ ) in La Croix.

Table 1 shows the weather conditions during periods of plant growth. The growth and development of hemp is predominantly dependant on temperature and photoperiod/radiation (Van Der Werf et al., 1995; Amaducci et al., 2008). The end of flowering stage of Fedora 17, Santhica 27 and Futura 75 was obtained after $2163^{\circ} \mathrm{C}, 2308^{\circ} \mathrm{C}$ and $2545{ }^{\circ} \mathrm{C}$ cumulative degree days base $0{ }^{\circ} \mathrm{C}$ (corresponding to 116,103 and 123 calendar days) respectively in agreement with the ranking of these cultivars regarding precocity. As the Alès site received little rain during the growth phase of hemp ( $98 \mathrm{~mm}$ versus $242 \mathrm{~mm}$ for La Croix) we can estimate that the soil reserve must have been fully used over its entire depth $(1 \mathrm{~m})$, thereby enabling the plant to reach its full flowering stage. The seed maturity of the latest cultivar, Futura 75, is observed after a longer period following sowing, compared to Fedora 17 (3294 versus 2728 cumulative degree days respectively). This classification is also found by considering the "global radiation" variable, with Piacenza $>$ La Croix. Overall, we can estimate that the cultivation site has no marked effect on the hemp harvest dates, despite fairly different soil conditions between Alès and Piacenza (clay loam soil) versus La Croix (highly chalky soil).

The climatic environment during the retting of hemp is presented in Table 2 and shows large variations depending on the experimental sites. Despite a nearly identical number of calendar days (72 and 77), the entire retting period (R0-R2) lasted 36.5 and 108.5 standard days accumulated at $15{ }^{\circ} \mathrm{C}$ (SD) in La Croix and Alès respectively. This difference is even more pronounced in the first period retting (R0-R1) which took 19.9 SD in La Croix and 62.2 SD in Alès, indicating an extended duration of the retting time in Alès, despite warmer environmental conditions and a much higher global radiation $\left(563 \mathrm{MJ} / \mathrm{m}^{2}\right)$ compared to La Croix $\left(183 \mathrm{MJ} / \mathrm{m}^{2}\right)$. Since standard days normalise the data with respect to temperature only, the /extension of the retting time could be explained by the very limited precipitation in addition to a relatively high level of solar radiation, which may prevent optimal development of microorganisms at the surface of the stems. The retting period in Piacenza was similar to that of La Croix with respect to standard days (35) while cumulative global radiation (415 and $350 \mathrm{MJ} / \mathrm{m}^{2}$ ) was in the same range. Rainfall is three times more important during the second retting period of Fedora 17 in La Croix, and this may impact the microbial diversity as oxygen may be less available when there is excess water in the windrows. However, the retting of Fedora was performed on highly chalky soil, which is more prone to drainage and infiltration of water compared to clay-loam soils of Piacenza and Alès. Moreover, Fedora 17 was harvested for dual purposes using a combine harvesting

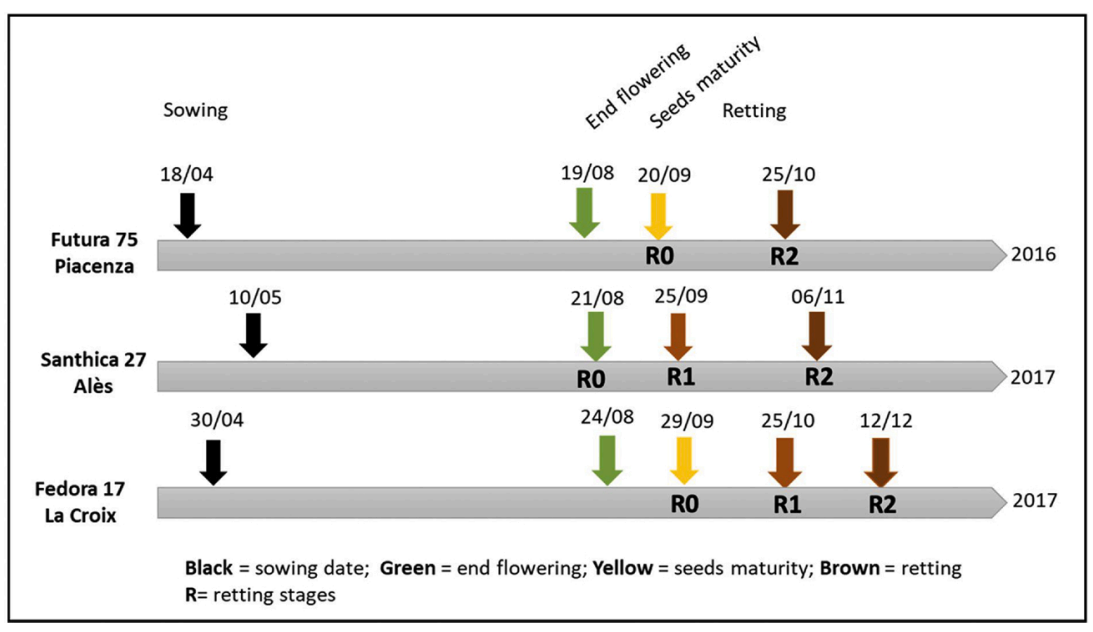

Fig. 2. Simplified diagram of crop management. 


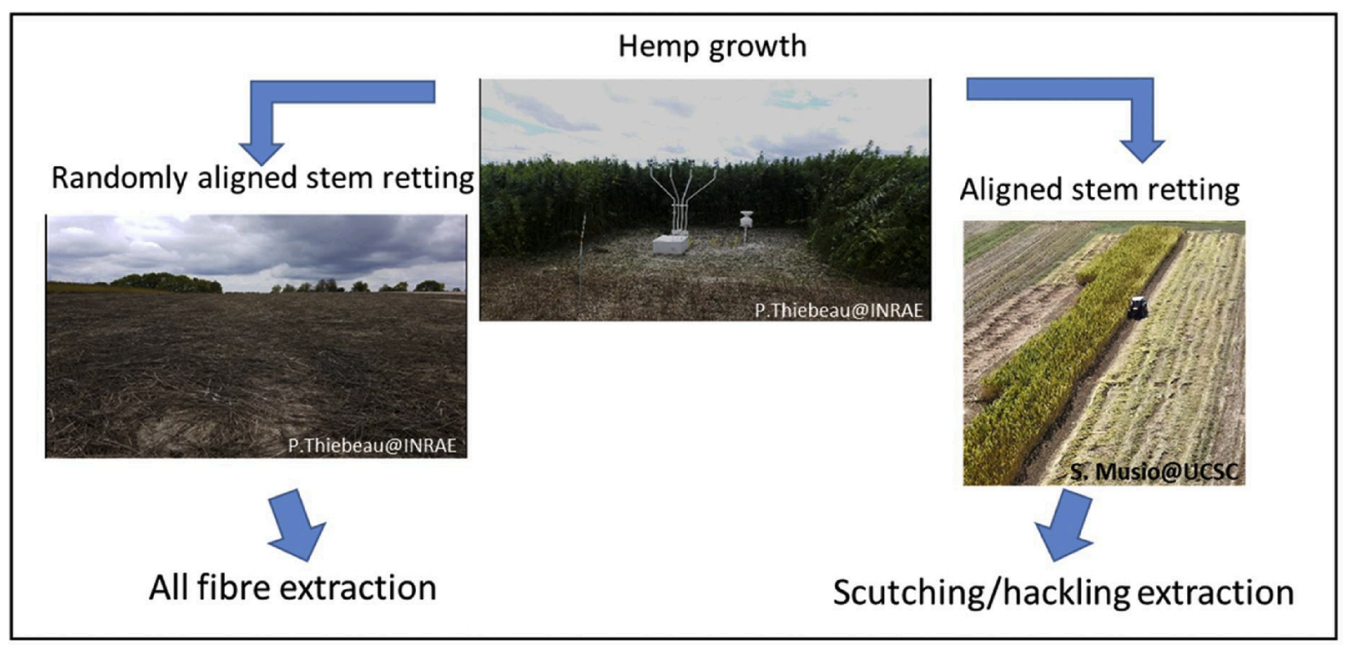

Fig. 3. Growth and field retting of randomly oriented and aligned stems.

Table 1

Climatic environment of crops between sowing and the onset of retting.

\begin{tabular}{|c|c|c|c|c|c|}
\hline Variety and experimental site & Growth stages & Period & Cumulative standard days ${ }^{\mathrm{a}}\left({ }^{\circ} \mathrm{C}\right)$ & Cumulative global radiation $\left(\mathrm{MJ} / \mathrm{m}^{2}\right)$ & Cumulative rains $(\mathrm{mm})$ \\
\hline \multirow{2}{*}{ Futura 75 (Piacenza) } & Sowing to end flowering & $\begin{array}{l}18 / 04-19 / \\
08\end{array}$ & 258 & 3292 & $268^{\mathrm{b}}$ \\
\hline & Sowing to seeds maturity & $\begin{array}{l}18 / 04-20 / \\
09\end{array}$ & 343 & 3987 & $441^{\mathrm{b}}$ \\
\hline Santhica 27 (Alès) & Sowing to end flowering & $\begin{array}{l}10 / 05-21 / \\
08\end{array}$ & 253 & 2394 & 98 \\
\hline Fedora 17 (La Croix) & Sowing to end flowering & $\begin{array}{l}30 / 04-24 / \\
08\end{array}$ & 191 & 2332 & 242 \\
\hline
\end{tabular}

a) Base $0{ }^{\circ} \mathrm{C}$; b) Including $75 \mathrm{~mm}$ of irrigation.

Table 2

Climatic environment during hemp retting.

\begin{tabular}{|c|c|c|c|c|c|c|}
\hline $\begin{array}{l}\text { Variety (experimental } \\
\text { site) }\end{array}$ & $\begin{array}{l}\text { Retting } \\
\text { stage }\end{array}$ & Period & $\begin{array}{l}\text { Number of calendar } \\
\text { days }\end{array}$ & $\begin{array}{l}\text { Cumulative normalised days at } \\
15{ }^{\circ} \mathrm{C}\end{array}$ & $\begin{array}{l}\text { Cumulative global radiation } \\
\left(\mathrm{MJ} / \mathrm{m}^{2}\right)\end{array}$ & $\begin{array}{l}\text { Cumulative rains } \\
(\mathrm{mm})\end{array}$ \\
\hline Futura 75 (Piacenza) & R0-R2 & $\begin{array}{l}20 / 09-25 / \\
10\end{array}$ & 35 & 35.7 & 415 & 69 \\
\hline \multirow[t]{2}{*}{ Santhica 27 (Alès) } & R1-R2 & $\begin{array}{l}25 / 09-06 / \\
11\end{array}$ & 42 & 46.3 & 469 & 124 \\
\hline & R0-R2 & $\begin{array}{l}21 / 08-06 / \\
11\end{array}$ & 77 & 108.5 & 1032 & 138 \\
\hline \multirow[t]{2}{*}{ Fedora17 (La Croix) } & R1-R2 & $\begin{array}{l}25 / 10-12 / \\
12\end{array}$ & 48 & 16.6 & 167 & 157 \\
\hline & R0-R2 & $\begin{array}{l}29 / 09-12 / \\
12\end{array}$ & 72 & 36.5 & 350 & 209 \\
\hline
\end{tabular}

machine to collect the seeds. At the back of the machine a windrow composed of randomly aligned stems was implemented and such a random organisation of the stems could also facilitate the drainage of excess water. In contrast, the Santhica 27 and Futura 75 dew-retting was managed by arranging regularly aligned stems with homogeneous thickness, thereby preventing excess drying of soil in contact with the windrows. Such an effect could be enhanced in Alès and Piacenza, where a clay loam soil would lead to higher moisture retention than a high chalk soil, despite dryer climate conditions.

Based on these major environmental differences, an essential query depends on retting homogeneity and the possibility of controlling the activity of the microorganisms, their progress and the impact at stem and fibre level. The microflora involved in field retting is relatively well known in the case of flax fibres (Djemiel et al., 2017) and hemp fibres (Ribeiro et al., 2015) (Law et al., 2020) and is affected by soil type, harvest period, climatic conditions, and retting time. Interestingly, based on $16 \mathrm{~s}$ rRNA sequencing study, it was reported recently that in a controlled environment, the moisture level had an impact on the retting microorganism populations whereas the soil variable did not influence the microorganism community, suggesting a resilient and epiphytique population present on the stems (Law et al., 2020). The retting process is thus highly dependent on weather conditions, which is a major risk to the survival of the crop. An increase in precipitation leads to an increase in moisture content in the stems, which may make their collection 
impossible. It is also important to avoid over-retting which can lead to degradation of the cellulosic fibres.

\subsection{Hemp fibre extraction}

Fedora 17 fibres were extracted from straw by FRD (Troyes, France) at pilot scale, using a $100 \%$ mechanical process suitable for all bast fibres. The straw was successively subjected to breaking and beating rollers followed by cleaning. Standard hemp straw parameters (speed of rolling, pressure on straw, intensity of cleaning), resulting from 10 years of experimentation at pilot scale, were used for these samples, to obtain the best compromise between the efficiency of the process and a high level of shive removal. Regarding the batches of Futura 75 and Santhica 27, the fibres were extracted by ENIT in Tarbes using a lab-scale scutching and hackling device developed by Taproot Fibre Lab (Nova Scotia, Canada). The device, composed of three modules, produces long aligned fibres without shives at the end of the scutching/hackling process. The raw material, in the form of aligned stems, is introduced into a breaking device consisting of three successive pairs of fluted rollers. This part of the process breaks the woody part of the hemp stems and begins the extraction of the shives. At the end of the breaking process the hemp is transferred to a scutching module composed of two rotating blades that strike the material, thereby extracting the vast majority of the remaining shives and plant dust trapped in the fibres. Finally, the product obtained at the end of the scutching process is introduced into a hackling module to align the fibres and separate the fibre bundles (Fig. 4). The Santhica 27 hemp fibres used for manufacturing injection moulding composites were manually extracted from the stems.

\subsection{Composite manufacturing}

\subsubsection{Polymers}

A partially bio-based epoxy resin (SR GreenPoxy 56 from SICOMIN) was used to prepare the unidirectional composites from the 3 varieties with a proportion of 100:37 wt ratio between the resin and the hardener (SD Surf Clear).

Two types of polypropylene (PP) were used as a matrix for injectionmoulded composites. i) PPC10642 from Total Petrochemicals ${ }^{\circledR}$ with a melt flow index of $44 \mathrm{~g} / 10 \mathrm{~min}$ at $230{ }^{\circ} \mathrm{C}$ (under a load of $2.16 \mathrm{~kg}$ ) was used for manufacturing the composites reinforced with Fedora 17 hemp fibres. ii) PP H733-07 provided by Braskem with a melt flow rate of 7.5 $\mathrm{g} / 10 \mathrm{~min}\left(230{ }^{\circ} \mathrm{C}, 2.16 \mathrm{~kg}\right)$ was used for processing the composites reinforced with Santhica 27 hemp fibres. In order to improve the compatibility between the fibres and the PP matrix, maleic anhydride grafted PP (PPgMA), OREVAC 100 (Arkema) was used.
The final PP blends used are $96 \%$-wt PP and $4 \%$-wt PPgMA and 99 $\%$ PP and $1 \%$-wt PPgMA for composites with Fedora 17 and Santhica 27 hemp fibres, respectively.

\subsubsection{Unidirectional hemp fibre/epoxy composites manufacturing}

Fibre bundles were extracted from stems and manually aligned to form a unidirectional bundle of around $10 \mathrm{~cm}$ in length. The bundles were dried at $60{ }^{\circ} \mathrm{C}$ for $24 \mathrm{~h}$ and then impregnated with epoxy resin for good fibre/matrix interface (Coroller et al., 2013) and to obtain unidirectional biocomposites with a targeted volume fraction. The impregnated R0, R1 and R2 fibre bundles were placed in an aluminium mould of $6 \times 2 \mathrm{~mm}^{2}$ section open at each end to evacuate the excess resin during compression. Given the small section size, the resin flow is mainly longitudinal and is assumed to have a reduced effect on mis-orientation. The samples were then cured under a temperature cycle of $24 \mathrm{~h}$ at $23^{\circ} \mathrm{C}+4 \mathrm{~h}$ at $40^{\circ} \mathrm{C}+8 \mathrm{~h}$ at $60^{\circ} \mathrm{C}$, (curing cycle proposed by the supplier).

\subsubsection{Compounding and injection moulding of hemp fibre/PP composites}

Prior to injection moulding, R0, R1 and R2 Fedora 17 and Santhica 27 fibres were mechanically and manually cut at a target length of 2 $\mathrm{mm}$. The $2 \mathrm{~mm}$ hemp fibres were dried under a vacuum at $60{ }^{\circ} \mathrm{C}$ for $12 \mathrm{~h}$ prior to extrusion.

Composites reinforced with Fedora 17 fibres were prepared using a laboratory-scale twin-screw co-rotating extruder TSA with a screw diameter of $20 \mathrm{~mm}$, and length/diameter ratio of 40 . The twin-screw profile includes conveying elements, a venting zone for the evacuation of steam and 3 kneading blocks. Polymers and hemp fibres (30\%-wt) were introduced before the three kneading zones at the beginning of the barrel. A fixed barrel temperature of $190^{\circ} \mathrm{C}$ was set for the whole screw profile. The total feed rate was $3 \mathrm{~kg} / \mathrm{h}$ for all blends with a screw speed of $100 \mathrm{rpm}$. After the extrusion step, the formulations were immediately put into a cold-water container, and then pelletised into approximately 3-mm length granules. Injection moulding was carried out on a Battenfeld BA 800 machine. The mould temperature was maintained at 30 ${ }^{\circ} \mathrm{C}$ for all the compounds. The compounds were injected into a mould designed to produce ISO-527 normalised specimens. The screw temperature was set to $190^{\circ} \mathrm{C}$.

Composites reinforced with Santhica 27 fibres (30\%-wt) were prepared using a twin-screw micro-compounder (DSM Xplore, microcompounder, Geleen, Netherlands, $15 \mathrm{~cm}^{3}$ ) with a temperature profile of $180{ }^{\circ} \mathrm{C}$ (feeder) $-180{ }^{\circ} \mathrm{C}$ (middle screw) $-200{ }^{\circ} \mathrm{C}$ (die) and a screw speed of $80 \mathrm{rpm}$. The extruded pellets were dried for 3 days at $60^{\circ} \mathrm{C}$, then injection moulded using a IM15 Zamak Mercator machine (Skawina, Poland) with a barrel temperature of $195{ }^{\circ} \mathrm{C}$. Tensile dog-bone

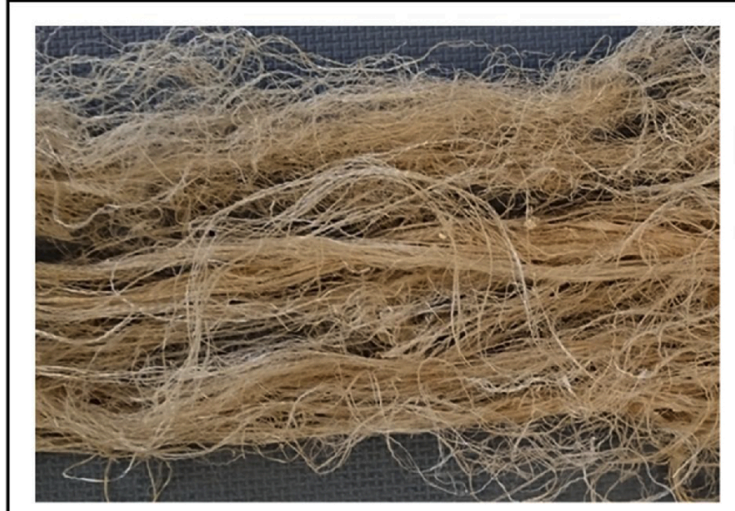

(a) Hemp extracted fibres at the Output of FRD line

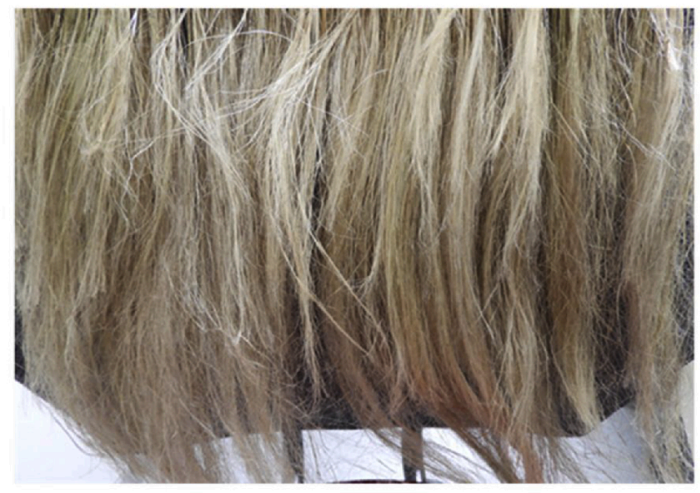

(b) Hemp extracted fibres at the output of the labscale scutching/hackling line

Fig. 4. Hemp fibres at the output of the extraction processes. 
specimens corresponding to the ISO 527-2 type-1BA were obtained.

\subsection{Fibre and composite mechanical characterisation}

\subsubsection{Tensile tests on elementary hemp fibres}

Tensile tests on Fedora 17 elementary fibres were carried out according to the NFT 25-501-2 standard, which takes into consideration the compliance of the load sensor. A minimum of 60 fibres manually extracted from bundles at different retting degrees (R0, R1, R2) were tested. Before testing, single fibres were bonded onto a paper frame to obtain a fixed gauge length of $10 \mathrm{~mm}$ and conditioned for $24 \mathrm{~h}$ at a controlled temperature and humidity of $23{ }^{\circ} \mathrm{C}$ and $50 \%$, respectively. The diameter of each fibre was determined using an optical microscope, the value corresponding to the mean of six measurements taken along the fibre. Here, one considers that the fibres are perfectly cylindrical and the lumen area is neglected in the fibre cross-section evaluation. The paper frame was then clamped onto a universal MTS tensile testing machine equipped with a $2 \mathrm{~N}$ capacity load sensor, and tested at a crosshead speed of $1 \mathrm{~mm} / \mathrm{min}$.

The mechanical properties of the individual fibres of the Santhica 27 and Futura 75 varieties were determined using a micro-tensile testing device developed by Dia-stron Ltd. (Hampshire, UK). Before testing, the individual fibres were carefully and manually extracted from the fibre bundles and positioned at each end in plastic tabs and glued with a UVcuring resin to prevent the fibres from slipping during the tensile tests. A gauge length of $12 \mathrm{~mm}$ was used for these tests. The section of these fibres was first measured with an automated laser scanning module, FDAS (Dia-stron Ltd., Hampshire, UK)) which uses a shadow projection technique (Garat et al., 2018). The fibres are horizontally rotated within the laser beam at 10 slices along the fibre axis. The maximum and minimum diameters of the fibre section were measured for each position and each local section area was computed using an elliptical model which was shown to be more accurate by Garat et al. (Garat et al., 2018). Here also, the lumen area is not taken into account in the cross-section evaluation. All the 10 local values of all the local sections were used to determine the mean section of each fibre. After the determination of the fibre section, tensile tests were then carried out on the same fibres using an automated high-precision extensometer (Lex 820, Dia-Stron Ltd., Hampshire, UK) with a load cell capacity of $20 \mathrm{~N}$ at a displacement speed of $1 \mathrm{~mm} / \mathrm{min}$. The breaking stress also called fibre strength and elastic modulus (taken as the initial slope of the stress-strain curve) of each fibre were calculated following these tests. For each batch, a minimum of 60 single fibres were tested in controlled temperature and humidity.

\subsubsection{Tensile characterisation of composite materials}

Tensile tests on Fedora 17 based unidirectional hemp-epoxy and hemp-PP biocomposites were performed using a 5566 Instron testing machine at a controlled temperature $\left(23{ }^{\circ} \mathrm{C}\right.$ and $\left.\mathrm{RH}=48 \%\right)$ at a crosshead speed of $1 \mathrm{~mm} / \mathrm{min}$. A $10 \mathrm{kN}$ force sensor was used to measure the load and an axial extensometer with a nominal length of $25 \mathrm{~mm}\left(\mathrm{~L}_{0}\right)$ was used to measure the strain.

For characterisation of Santhica 27 and Futura 75 unidirectional composites, a universal testing machine (Instron 4204) with a load cell of $5 \mathrm{kN}$ run at a crosshead displacement speed of $1 \mathrm{~mm} / \mathrm{min}$ was used. A clip-on extensometer with a $30 \mathrm{~mm}$ initial length was used to measure the strain locally.

\subsubsection{Impregnated fibre bundle test (IFBT)}

The IFBT procedure as defined by Bensadoun et al. (2015) was used to compute the tangent modulus and strength from the mechanical properties of unidirectional composites using the Rule-of-Mixtures (ROM) according to Eq. (1) and (2):

$E_{L, f}=\frac{E_{c}-E_{m} \cdot\left(1-V_{f}\right)}{V_{f}}$ $\sigma_{f}=\frac{\sigma_{c}-\sigma_{m} \cdot\left(1-V_{f}\right)}{V_{f}}$

where $E_{, f}$ is the longitudinal modulus of the fibre, $E_{m}$ is the modulus of the matrix (3.3 GPa) and $V_{f}$ is the fibre volume fraction, $\sigma_{\mathrm{f}}$ is the longitudinal strength of the fibre and $\sigma_{\mathrm{m}}$ the stress of the matrix (51 MPa) at the composite failure strain. For this analysis, the void content was assumed to be null. The unidirectional composite fibre volume fraction was set to $30 \%$ as given in Table 3 .

\subsection{Composites microstructure characterisation}

The composites microstructure was studied to evaluate the impact of retting on individualization of hemp bundles during composites processing. In the case of Fedora 17 hemp fibre/PP composites, fibre lengths and diameters after injection moulding were characterised. In order to separate hemp fibres from the PP matrix, parts of injected samples were Soxhlet extracted in hot xylene for $15 \mathrm{~h}$ and then dried overnight at 70 ${ }^{\circ} \mathrm{C}$ to remove excess solvent and moisture. For fibre size and shape measurements, the dynamic particle analysis system QICPIC combined with dry dispersion unit RODOS (Sympatec GmbH, Germany) were used. For the three considered batches, the fibres were analysed before processing and after PP dissolution. To measure the fibre length and diameter, Lefi and Difi parameters, representing the length and diameter of fibre elements, respectively were considered. Results were obtained using WINDOX software (Sympatec GmbH, Germany). More than 1 million fibres were analysed for each batch. The fibre length was defined as the shortest path between the most distant end points of the particle after skeletonising its projected area and the fibre diameter was calculated by dividing the projected area by the added length of all skeleton paths.

In addition, individualisation of fibre bundles was estimated on Fedora 17 unidirectional composite cross-sections. The sections of the fibre bundles were isolated on the SEM images using the GIMP ${ }^{\circledR}$ software and their areas were analysed with the ImageJ $₫$ software. The ratio of single fibres was calculated by considering single fibres when their equivalent diameter was under the average diameter determined for tensile tests (Table 3).

\subsection{Fibre characterisation}

\subsubsection{Cellulose crystallinity}

The cellulose crystallinity was determined by wide-angle X-ray diffraction measurements performed on $2 \mathrm{~mm}$ cut length fibre bundle samples under ambient conditions subjected to Siemens D500 diffractometer $\mathrm{CuK}$, radiation. Samples were loaded on a silicon wafer and scans were collected from $2 \theta=10$ to $40^{\circ}$ with step size of $0.03^{\circ}$ at $2 \mathrm{~s} /$ step, at $30 \mathrm{kV}$ and $20 \mathrm{~mA}$. Crystallinity was calculated using (3),

$C=\frac{I_{t o t}-I_{a m}}{I_{t o t}} * 100$

where $\mathrm{I}_{\text {tot }}$ is the intensity at the primary peak for cellulose I (at $2 \theta \approx$ $22.5^{\circ}$ ) and $\mathrm{I}_{\mathrm{am}}$ is the intensity from the amorphous portion evaluated as the minimum intensity (at $2 \theta \approx 18.5$ ).

\subsubsection{Fibre surface}

A Jeol JSM 6460LV scanning electron microscope (SEM) was used to analyse the cross-section of hemp/epoxy unidirectional composites as well as hemp/PP injected composites. Unidirectionnal composites were cut perpendicularly to the fibre direction and injected composites perpendicularly to the injection direction.

The fibre orientation was observed after polishing the surface and the mid-plane of the injected sample in the plane, parallel to the flow. Prior to the observations, all samples were sputter coated with gold using an Edwards Scancoat Six device. At least ten images were taken of 
Table 3

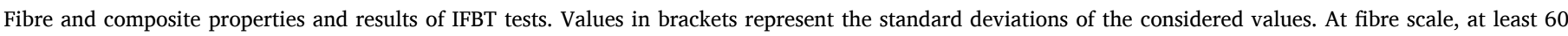

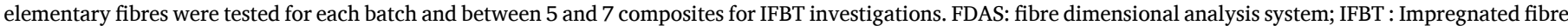
bundle test and Vf: fibre volume fraction. $\Delta \mathrm{R}$ is the evolution of the value (in \%) between R0 and R1 or R0 and R2.

\begin{tabular}{|c|c|c|c|c|c|c|c|c|c|c|c|}
\hline & \multicolumn{3}{|c|}{ FUTURA 75} & \multicolumn{4}{|c|}{ SANTHICA 27} & \multicolumn{4}{|c|}{ FEDORA 17} \\
\hline & R0 & $\mathrm{R} 2$ & $\begin{array}{l}\Delta \mathrm{R}(\%)(\mathrm{R} 0- \\
\mathrm{R} 1)\end{array}$ & R0 & $\mathrm{R} 1$ & $\mathrm{R} 2$ & $\begin{array}{l}\Delta \mathrm{R}(\%)(\mathrm{R} 0- \\
\mathrm{R} 2)\end{array}$ & R0 & $\mathrm{R} 1$ & $\mathrm{R} 2$ & $\begin{array}{l}\Delta \mathrm{R}(\%)(\mathrm{R} 0- \\
\mathrm{R} 2)\end{array}$ \\
\hline \multicolumn{12}{|l|}{ FIBRE SCALE } \\
\hline & \multicolumn{7}{|c|}{ FDAS measurement } & \multicolumn{4}{|c|}{ Optical microscope measurement } \\
\hline Diameter $(\mu \mathrm{m})$ & $\begin{array}{l}18.5 \\
(4.2)\end{array}$ & $17.0(4.5)$ & -7.9 & $19.9(5.8)$ & $18.9(6.4)$ & $19.0(6.0)$ & -4.8 & $\begin{array}{l}24.5 \\
(2.8)\end{array}$ & $\begin{array}{l}22.4 \\
(3.9)\end{array}$ & $\begin{array}{l}20.4 \\
(5.8)\end{array}$ & -16.7 \\
\hline $\begin{array}{l}\text { Tangent modulus } \\
\text { (GPa) }\end{array}$ & $52(34)$ & $48(24)$ & -7.7 & $48(17)$ & $44(12)$ & $50(17)$ & +4.2 & $26(9)$ & $24(10)$ & $29(6)$ & +11.5 \\
\hline $\begin{array}{l}\text { Tensile strength } \\
\text { (MPa) }\end{array}$ & $\begin{array}{l}795 \\
(423)\end{array}$ & $822(400)$ & +3.4 & $732(550)$ & $788(342)$ & $855(626)$ & +16.8 & $\begin{array}{l}410 \\
(228)\end{array}$ & $\begin{array}{l}427 \\
(198)\end{array}$ & $\begin{array}{l}440 \\
(169)\end{array}$ & +7.3 \\
\hline Strain at break (\%) & $3.1(1.1)$ & $3.1(1.0)$ & +1.0 & $2.7(0.8)$ & $2.9(0.8)$ & $2.9(0.9)$ & +6.9 & $2.9(1.2)$ & $2.9(1.0)$ & $2.5(0.9)$ & -13.8 \\
\hline \multicolumn{12}{|c|}{ COMPOSITE SCALE UD } \\
\hline Vf (\%) & 30 & & & 30 & & & & 30 & & & \\
\hline $\begin{array}{l}\text { Tangent modulus } \\
\text { (GPa) }\end{array}$ & $\begin{array}{l}16.0 \\
(2.0)\end{array}$ & $15.6(3.2)$ & -2.5 & $17.4(4.0)$ & $17.5(3.2)$ & $15.0(4.0)$ & -13.8 & $12.7(2)$ & $\begin{array}{l}13.4 \\
(1.3)\end{array}$ & $\begin{array}{l}12.9 \\
(2.1)\end{array}$ & +1.5 \\
\hline $\begin{array}{l}\text { Tensile strength } \\
\text { (MPa) }\end{array}$ & $175(28)$ & $155(33)$ & -11.4 & $151(75)$ & 155 (49) & $170(34)$ & +13.9 & $116(18)$ & $115(12)$ & $122(19)$ & +4.9 \\
\hline Strain at break (\%) & $1.8(0.3)$ & $1.6(0.4)$ & -8.5 & $1.9(0.4)$ & $1.8(0.5)$ & $1.8(0.4)$ & -2.1 & $1.4(0.1)$ & $1.3(0.2)$ & $1.5(0.1)$ & +6.5 \\
\hline \multicolumn{12}{|l|}{ IFBT RESULTS } \\
\hline $\begin{array}{l}\text { Tangent modulus } \\
\text { (GPa) }\end{array}$ & $\begin{array}{l}47.0 \\
(6.0)\end{array}$ & $\begin{array}{l}46.0 \\
(10.0)\end{array}$ & -2.1 & $\begin{array}{l}50.3 \\
(12.0)\end{array}$ & $\begin{array}{l}50.6 \\
(11.0)\end{array}$ & $\begin{array}{l}43.6 \\
(12.0)\end{array}$ & -13.3 & $\begin{array}{l}39.0 \\
(6.1)\end{array}$ & $\begin{array}{l}41.5 \\
(3.8)\end{array}$ & $\begin{array}{l}39.7 \\
(6.3)\end{array}$ & +1.7 \\
\hline $\begin{array}{l}\text { Tensile strength } \\
\text { (MPa) }\end{array}$ & 470 (98) & 421 (93) & -10.4 & $384(225)$ & $397(150)$ & $447(112)$ & +16.4 & $335(55)$ & $332(36)$ & $357(56)$ & +6.1 \\
\hline
\end{tabular}

each sample, and the representative ones were selected to create the figures for the present paper.

\section{Results and discussion}

\subsection{Cellulose crystallinity evolution during the retting process}

Cellulose content and particularly crystallinity are important biochemical and physicochemical properties that play a leading role in fibre properties (A. Bourmaud et al., 2018). X-ray diffraction studies were conducted to monitor the evolution of cellulose organisation in the fibres during the retting process. The diffraction pattern of cellulose I (Fig. 5a) shows two main reflection peaks for the crystalline phases at $2 \theta$ $\approx 15^{\circ}$ (101 diffraction plane) and $22.5^{\circ}$ (002), with the amorphous phase observed at $2 \theta \approx 18.5^{\circ}$ (method described in Park et al., 2010 and first proposed by Segal et al. (1962)). These reference peaks were used to analyse the XRD spectra of the various hemp fibre samples (Fig. 5a).

All samples exhibit a primary peak at $2 \theta \approx 22.5^{\circ}$ corresponding to the crystalline (002) plane of cellulose I. The shape of this peak is relatively fine for Futura 75 and Santhica 27 but slightly broader for
Fedora 17 fibres. Fedora 17 exhibits a lower crystallinity value compared to Santhica 27 and Futura $75(-14.1 \%$ and $-11.9 \%$ for R0 samples, respectively). For Fedora 17, the extraction mode is different and probably more aggressive on fibre integrity. Moreover, this type of extraction leaves more stem tissues surrounding fibre bundles (mainly parenchyma and/or epidermis). This may explain the lower degree of crystallinity (60\%) in these samples compared to the two other hemp varieties $(70 \%)$. As the highly crystalline cellulose I possesses the highest mechanical properties and as Fedora 17 exhibits a higher level of amorphization, Santhica 27 and Futura 75 fibres may be expected to present higher mechanical properties than Fedora 17 fibres.

The evolution of the crystallinity as a function of the dew retting time is plotted in Fig. 5b. In all three varieties, crystallinity remains fairly constant during the retting phase, especially for Futura 75 and Fedora 17. A slight increase is noted for Santhica 27 which is in good line with flax fibre measurements found in literature (A Bourmaud et al., 2018). Apart from this exception in our study, the two other samples do not show significant changes in fibre crystallinity during retting. If cellulose crystallinity, which is one of the main parameters controlling the mechanical properties of the plant fibres, does not change during
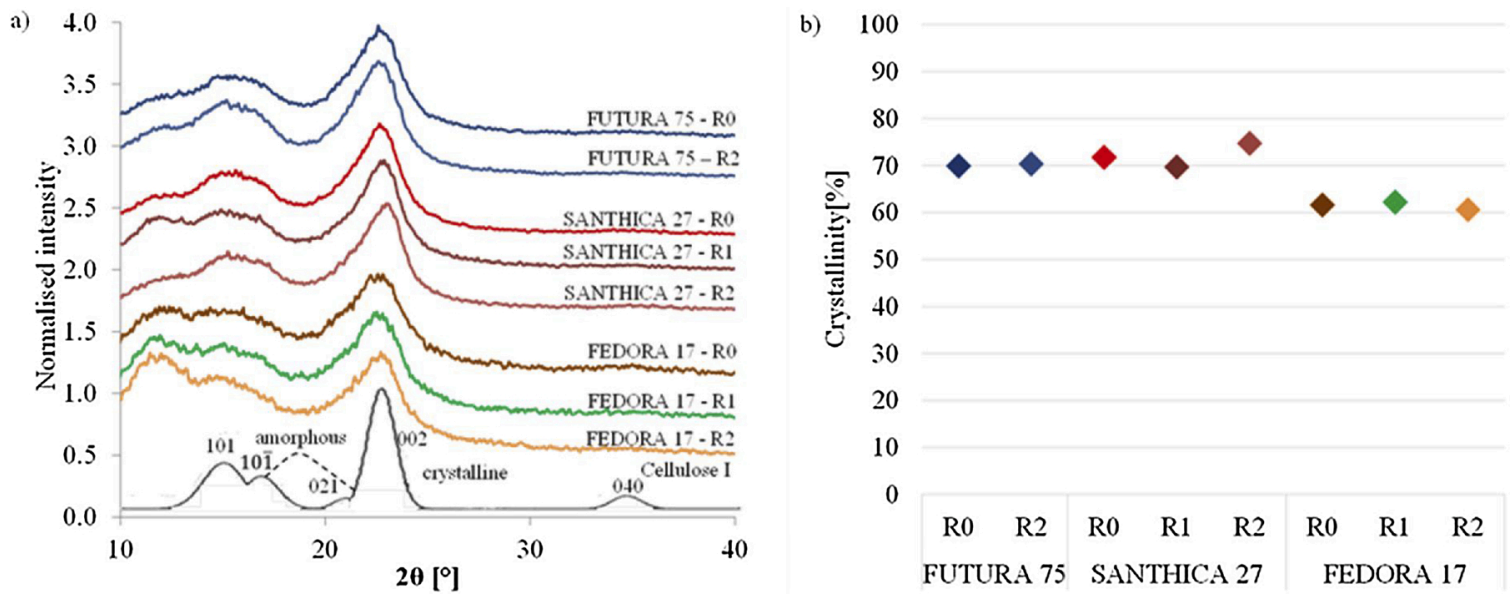

Fig. 5. X-ray spectra (A) and evolution of crystallinity (B) of various extracted fibres. 
field-retting, it can be expected that the tensile properties of the individual fibres will also not change.

\subsection{Evolution of mechanical properties of single hemp fibres during retting}

Table 3 reports the evolution of the mechanical properties (tangent modulus, strength and strain at break) of single hemp fibres for different levels of field retting for all three cultivars. The first information to note here is the fact that for Futura 75 and for Santhica 27 (at R0), high mechanical properties were obtained after scutching and hackling extraction ( $52 \pm 34$ and $48 \pm 17 \mathrm{GPa}$ for modulus and $795 \pm 423$ and $732 \pm 550 \mathrm{MPa}$ for strength, respectively). Such mechanical property values are higher than what is typically reported in the literature following classical "all fibre" mechanical extraction of hemp fibres (Grégoire et al., 2020b; Placet, 2009; Placet et al., 2012). In fact, they fall within the range of properties measured on the most carefully hand-extracted fibres (Marrot et al., 2013) or within the range of values obtained after careful lab-scale enzymatic retting and hand extraction (Liu et al., 2016). Scutching and hackling performed on flax machinery tested in an industrial preliminary trial by Musio et al. (2018) already showed promising results even though the fibre yield was relatively low. The properties obtained for hemp fibres in this study or in a recent study (Grégoire et al., 2020a) are at an individual fibre scale equivalent to those determined on industrially extracted flax, but $20 \%$ lower with respect to the IFBT tests (Bensadoun et al., 2017). It therefore places hemp fibres as a good source for load-bearing composite reinforcement.

Fedora 17 hemp fibres (R0) exhibit lower mechanical properties (tangent modulus ( $25 \pm 3 \mathrm{GPa})$ and strength $(410 \pm 228 \mathrm{MPa})$ ). These properties are comparable to properties determined by Placet et al. for the $25 \pm 11$ GPa modulus (Placet et al., 2012) obtained for hammer mill extracted fibres, and lower than properties obtained with all-fibre extraction (Grégoire et al., 2020b), which achieved a modulus of $38 \pm$ $11 \mathrm{GPa}$. It is difficult to conclude on significant differences in strength because the standard deviations are significantly large, even if Placet et al. (2012) and Grégoire et al. (2020b) found larger mean values, as the standard deviations are very broad and overlap. The lower values observed for Fedora 17 also confirm the crystallinity results (lower degree of crystallinity, $60 \%$ in comparison to $69 \%$ obtained by Marrot et al. (2013).

In first glance, it would appear that the Fedora 17 variety is not adapted to the production of load bearing fibres, but Marrot et al. (2013) and Bourmaud and Baley (2009) (44 $\pm 19 \mathrm{GPa}$ and $788 \pm 307 \mathrm{MPa}$ for modulus and strength, respectively) showed that when extracted manually, this variety could produce high tensile properties. However, Duval et al. (2011) showed that when extracted with aggressive lines such as hammer mills, the properties were much lower. The device used in this study to extract the Fedora 17 fibres is an all-fibre device composed of breaking and cleaning rollers which most likely apply excessively aggressive loads to the fibres. This most certainly damages them and decreases their degree of crystallinity, as is the also case for hammer mills.

It is important to note that all fibre" extraction devices have to be used if the fibres are randomly oriented, "contrary to scutching and hackling lines which require that straws be aligned at the machine entry. All-fibre or hammer mills should therefore be used for applications where excellent mechanical properties are not required, such as for reinforced plastics using injection moulding for example, as discussed later.

Our analysis of the evolution in mechanical performance with the degree of retting reveals no significant effects/changes for the three different batches, even though the field-retting was performed in significantly different environments and over different time scales. A Kruskal-Wallis non-parametric statistical analysis confirms the nonsignificant difference in performance between unretted (R0) and retted fibres (R2). This suggests that field retting does not alter the elementary fibre properties; this was hypothesised based on the constant levels of cellulose crystallinity for different retting levels within each batch. The results obtained in this work suggest that carefully-performed field retting does not have any effect on the tensile potential of hemp fibres and can be performed in different environments if it is wellmonitored and controlled. It is therefore interesting to investigate if the results obtained at single fibre scale are also observed at composite scale, as in that case fibre bundles or technical fibres are used.

When examining the tensile properties of single elementary fibres, one may observe major scattering due to many different causes such as: the fibre diameter (fine fibres promote higher modulus and strength values (Duval et al., 2011)), the number of transverse defects such as kink-bands (Hanninen et al., 2011), the location on the plant from which the fibre is extracted, the growth conditions (Baley et al., 2020), the method of extraction (already discussed above), the maturity of the fibre (influencing the lumen size and the thickness of the S2 wall (Goudenhooft et al., 2019)). As many different phenomena contribute to the variability of the elementary fibres, it is preferable to consider the results as mean values, without a precise analysis of the distribution of the values as long as the fibres are characterised under the same conditions for the sake of comparison.

It is also interesting to note that variability is also commonly encountered in single glass fibres (Coroller et al., 2013), especially as regards tensile strength, as glass fibres possess defects (Griffith and Taylor, 1921).

\subsection{Tensile properties of unidirectional epoxy/Fedora 17, Futura 75 and Santhica 27 hemp fibre composites: Influence of the dew retting time}

SEM images of unretted (Fig. 6.A) and retted (Fig. 6.B) reinforcements show transverse sections of unidirectional epoxy/Fedora 17 hemp fibre composites with similar fibre volume fraction. A substantial increase in fibre dissociation is observed between unretted and retted samples. Retting results in a degradation of the cementing substances (mainly non-cellulosic components such as hemicelluloses and pectins) present in the middle lamella within fibre bundles, leading to a potential modification in the fibre's surface biochemistry and a decrease in single fibre/fibre cohesion. Using image analysis to evaluate the reinforcement size (fibre bundles or single fibres), the percentage of single fibres was found to increase from about $26 \%$ for unretted composites to $40 \%$ for retted samples. This important increase in reinforcement individualization is linked to the impact of the retting process, by the alteration of the middle lamella which initially ensure fibre/fibre interface cohesion. The increase in single fibre content is well correlated with results from literature when flax bundles were subjected to specific chemical (Acera Fernández et al., 2016) or mechanical (Coroller et al., 2013) treatments to improve fibre individualization. One may therefore expect to obtain higher composite properties.

Table 3 synthesizes the mechanical properties of UD epoxy/hemp composites. Despite significant differences in terms of reinforcement individualization, no statistical difference in mechanical et al. is observed for the three investigated properties and this for all three varieties. In Table 3, the tensile properties of the composites are given for a fibre volume fraction of $30 \%$. The tensile properties of the Futura 75 and Santhica 27 show globally similar properties as was the case for single fibres. The Fedora 17 results for, such as for the single-fibre test, are also lower than for the other two hemp varieties. Globally speaking, a difference of $20 \%$ for the modulus and $30 \%$ for the strength can be observed between batches extracted using the scutching/hackling technique and the one extracted using an "all fibre" technique. It can be noted that this difference was higher at fibre scale (about $-100 \%$ for both modulus and strength).

The reinforcement potential of a composite (also called effective reinforcement properties) can be studied (both for rigidity and strength) via the Impregnated Fibre Bundle test (IFBT test, Table 3). The IFBT test results confirm the results obtained at fibre scale as well as at composite 


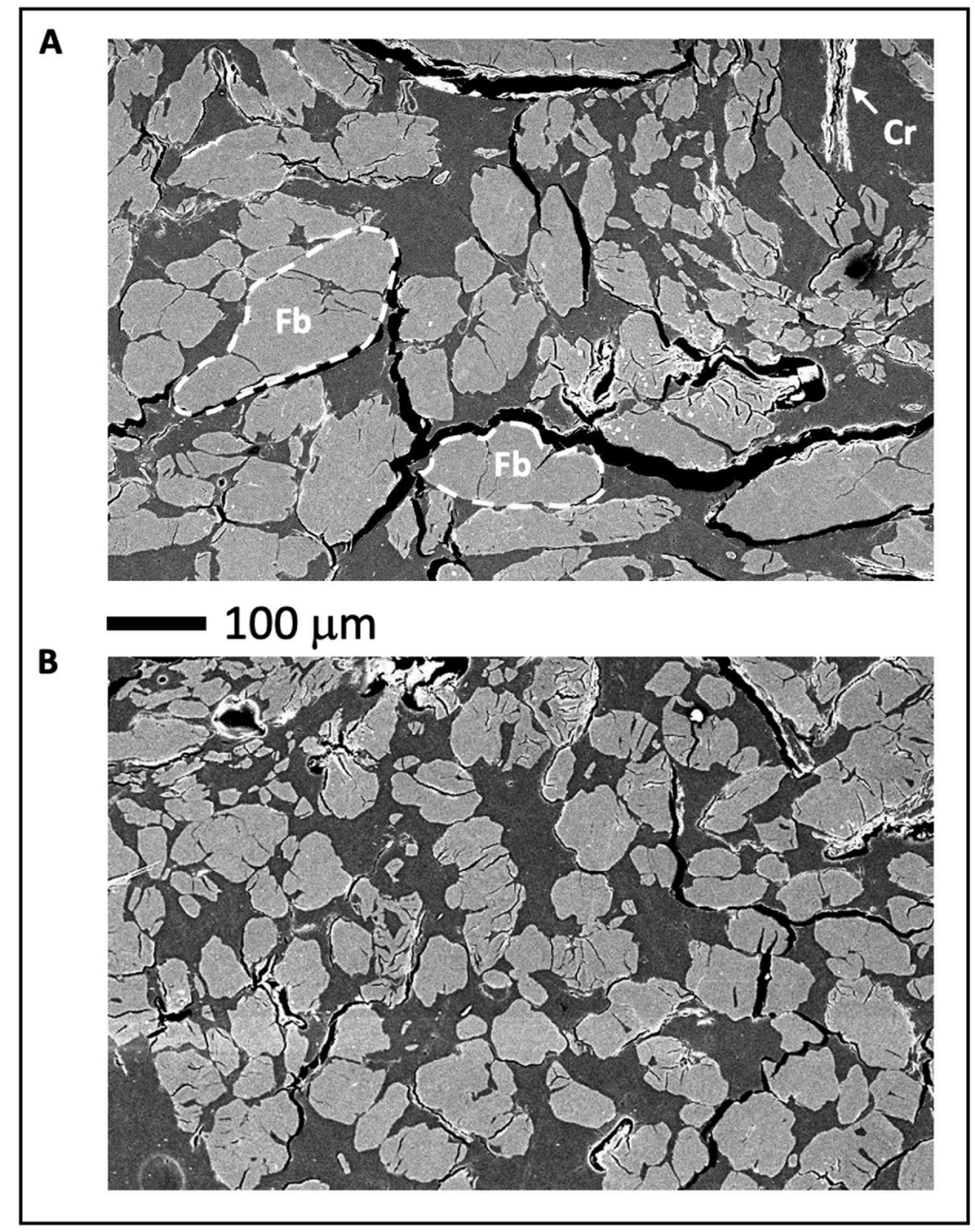

Fig. 6. SEM images of the transverse section of unretted (A) and retted R2 (B) unidirectional epoxy/Fedora 17 hemp-fibre composites. Fb: fibre bundle; Cr: remaining cortical residues.

scale. The results show that the effective tensile moduli of the Futura 75 and Santhica 27 fibres are high and globally equivalent to that of the individual fibres. As for strength, it is observed that the values are much lower than for the individual fibre tests by a factor of 1.9 for both varieties. This may be attributed to the fact that fibre bundles are used instead of individual fibres, with possible weak interfaces between individual fibres within the bundles, as well as to discontinuities in the fibre length, potentially leading to stress concentration in the resin in the vicinity of the fibre ends. For Fedora 17, the moduli determined using the IFBT procedure are much higher than those evaluated at fibre scale, even though technical fibres are used for IFBT.

The results at composite scale indicate that the real potential of the fibre (measured at the individual fibre scale) is not the only parameter to take into account when designing parts. Part of the fibre's strength is lost when passing to composite scale. This is not the case for the modulus. Impregnation of fibres such as those damaged during extraction may reveal some kind of repairing effect that needs to be confirmed by further studies and therefore even the "all fibre" extraction units may provide middle-range moduli for semi-structural parts and of course for injection-moulded composites.

The variability at composite scale (Table 3) decreases strongly in comparison to that observed at fibre scale. Because variability may have multiple causes, it is also preferable here to compare the potential of composites reinforced by long hemp fibres using mean values. However, when sizing composite parts that have to overcome a certain value, it is best to consider a composite strength or modulus value which is in the lower $5 \%$ fractile.

3.4. Tensile properties of injected PP/hemp composites: Influence of the dew retting time

Fig. 7 shows the results of tensile characterisation of injectionmoulded specimens composed of PP/hemp. Samples were manufactured from Fedora 17 and Santhica 27 fibres extracted at the three levels of field retting: R0, R1 and R2. Composites reinforced with Fedora 17 hemp fibres have significantly lower mechanical performances compared to the composites reinforced with Santhica 27 hemp fibres. This variation could be mostly related to the fibre mechanical performances, as noted in Section 3.3, as Santhica 27 hemp fibres have superior mechanical properties than Fedora 17 fibres, due essentially to the fibre extraction method. Other parameters may contribute to various behaviours such as the different PP grades with different viscosities used. However, our main objective here is to investigate if the level of retting has an influence on the mechanical properties of injected composites.

Fig. 7 shows, that similar behaviour to the fibres can be observed for 


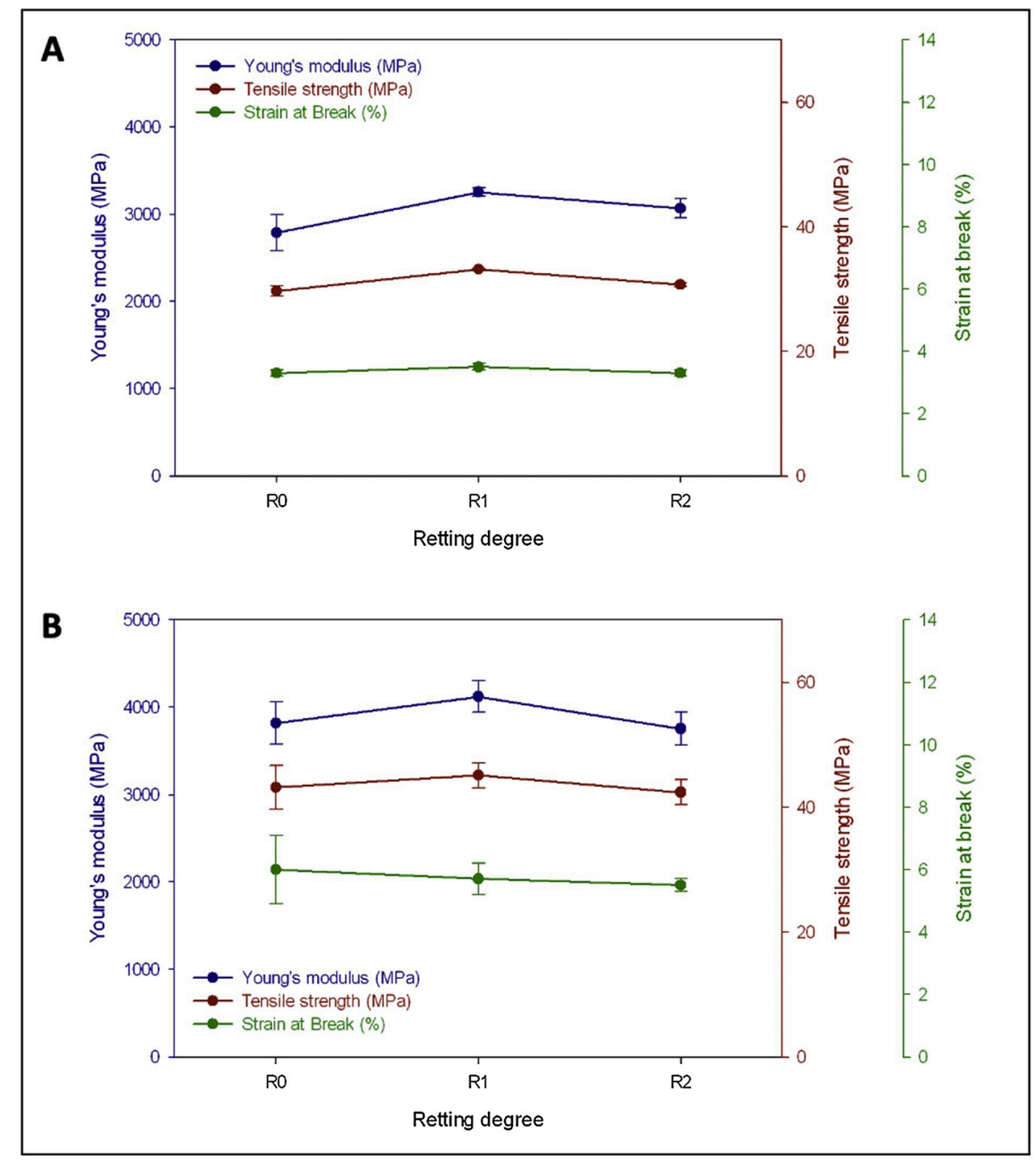

Fig. 7. Evolution in mechanical properties of injection-moulded hemp-PP composite with degree of fibre retting (R0, R1 and R2). A) Fedora 17 hemp fibre-PP composites and B) Santhica 27 hemp fibres-PP composites.

both injection moulded composites. The tensile strain at the breaking point remains stable for the various degrees of retting but a slight improvement can be noted in the tensile Young's modulus and strength at the breaking point in the first stage of retting (R1). These ones decreased with an extended retting treatment duration (R2). This type of behaviour can be explained by different factors such as the fibre division and preferential orientation of the fibres within the composite for the different degrees of retting, as demonstrated by Tanguy et al. (2018) on jute and flax injected PP composites.

Fig. 8 shows the fibre orientation at the centre of the R0 and R2

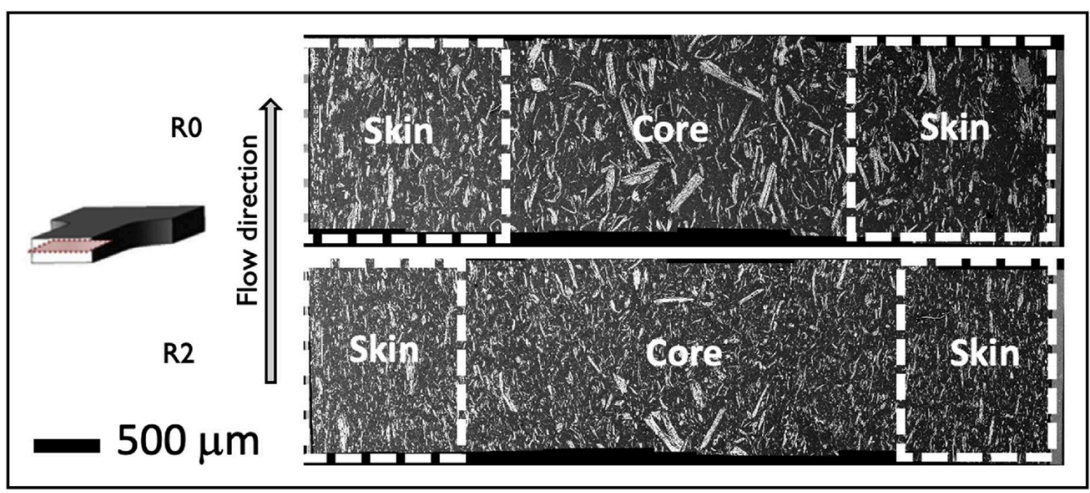

Fig. 8. SEM observation of microstructure of injected R0 and R2 Fedora 17 samples. White bordered square underlines fibre orientation difference between ski and core layer. 
injected part of Fedora 17. As expected, and generally observed on fibrereinforced injected composites, a difference can be seen in the fibre orientation between the skin and core layer of the specimen. Skin fibres are predominantly oriented in the mould flow direction whereas core fibres are more randomly oriented. Interestingly, the general orientation differs according to the degree of retting. For sample R2, the relative thickness of the skin fibres is lower, due to the morphology of the fibrous elements, as described by Tanguy et al. (2018). These observations are underlined by the morphological measurements of hemp fibres after processing. Fig. 9 shows the length distribution of R0, R1 and R2 fibres and Table 4 presents the values of length, diameter and aspect ratio, before and after injection moulding. R2 fibres are more divided due to more intensive retting. Conversely, R0 fibres have a larger diameter, which can lead to a higher bending stiffness. Even if the fibre diameters of the raw fibres are more pronounced, with an average value of $109 \pm$ $50 \mu \mathrm{m}$ and $73 \pm 39 \mu \mathrm{m}$ for batches R0 and R2, respectively, this difference remains significant after the injection moulding process. Actually, the diameter of the R2 fibres is $24 \%$ lower than that of the R0 fibres, penalising the skin-core effect and increasing the relative thickness of the core layer. Thus, R0 fibres are more readily oriented in the flow direction. The same observations were pointed out by Tanguy et al. on flax and jute fibres and by Graupner et al. (2016) on injected PLA/Lyocell composites. In addition, the presence of lignin-rich middle lamellae for R0 fibres also favours this easier orientation due to the cohesive and stiff character of bundles. In the case of hemp bundles, the presence of intact middle lamellae in R0 fibres also favours this easier orientation due, again, to the cohesive and stiff character of bundles. In fact, the middle lamellas of hemp are lignin-rich (Crônier et al., 2005), giving the bundles their high bending rigidity. During retting, the pectin in the hemp bundles' middle lamella (Bleuze et al., 2018) are enzymatically degraded and the cohesiveness of the bundle decreases and reduces the bending stiffness of the bundles, even if the lignin is not globally degraded.

In the present work, the difference in fibre orientation is not correlated with injected composite mechanical properties. As shown in Fig. 9, the size of the fibre elements evolves considerably between samples R0 and R2, with higher bundle individualization for sample R2 due to the impact of retting on the bundles' middle lamellae. Generally, this enhanced division favourably impacts the mechanical properties of the composite, limiting the presence of the bundles, which are potential
Table 4

Morphological values of Fedora 17 hemp fibres before and after injection moulding.

\begin{tabular}{|c|c|c|c|c|}
\hline Sample & $\begin{array}{l}\text { Number of particles } \\
\text { analyzed }\end{array}$ & $\begin{array}{l}\text { Length } \\
(\mu \mathrm{m})\end{array}$ & $\begin{array}{l}\text { Diameter } \\
(\mu \mathrm{m})\end{array}$ & $\begin{array}{l}\text { Aspect } \\
\text { ratio }\end{array}$ \\
\hline $\begin{array}{c}\text { R0 - Before } \\
\text { process }\end{array}$ & $2,829,303$ & $\begin{array}{l}1915 \pm \\
1233\end{array}$ & $109 \pm 50$ & 17.6 \\
\hline $\begin{array}{r}\text { R0 - After } \\
\text { process }\end{array}$ & $2,660,593$ & $642 \pm 437$ & $37 \pm 27$ & 17.4 \\
\hline \%change & - & $-66.5 \%$ & $-66.1 \%$ & $-1.0 \%$ \\
\hline $\begin{array}{l}\text { R1 - Before } \\
\text { process }\end{array}$ & $1,859,660$ & $\begin{array}{l}1743 \pm \\
1113\end{array}$ & $87 \pm 40$ & 20.1 \\
\hline $\begin{array}{r}\text { R1 - After } \\
\text { process }\end{array}$ & $2,150,178$ & $557 \pm 387$ & $29 \pm 17$ & 19.4 \\
\hline \%change & - & $-68.0 \%$ & $-66.9 \%$ & $-3.6 \%$ \\
\hline $\begin{array}{l}\mathrm{R} 2 \text { - Before } \\
\text { process }\end{array}$ & $3,644,518$ & $\begin{array}{l}1075 \pm \\
933\end{array}$ & $73 \pm 39$ & 14.8 \\
\hline $\begin{array}{r}\text { R2 - After } \\
\text { process }\end{array}$ & $3,779,707$ & $446 \pm 305$ & $28 \pm 19$ & 16.1 \\
\hline \%change & - & $-58.5 \%$ & $-62.1 \%$ & $-9.3 \%$ \\
\hline
\end{tabular}

weak/breakage areas as demonstrated by Bourmaud et al. (2013a). The present results do not evidence a clear difference between the mechanical properties of R0 and R2 composites; the negative effect of orientation for sample R2 is counterbalanced by greater division and finally, whatever the retting degree, the tensile properties of injected composite are globally of the same order of magnitude. In the case of injection-moulded composites, one can observe for batches of composites manufactured with different equipment and PP grades, that the modulus and strength are significantly higher at R1 in comparison to R0 and R2. While this is true for the modulus, it is not the case for strength for Santhica 27. These results however suggest that the best retting compromise may be an intermediate level in which bundle division is not too high and bundle stiffness is still high enough to favour a large skin-to-core thickness ratio.

\section{Conclusions}

The results presented in this work indicate that field retting (dew retting) can be achieved to a satisfactory degree in very different environments such as Eastern France, Southeast France and Northern Italy where the solar radiation, rainfalls and temperatures are very different.

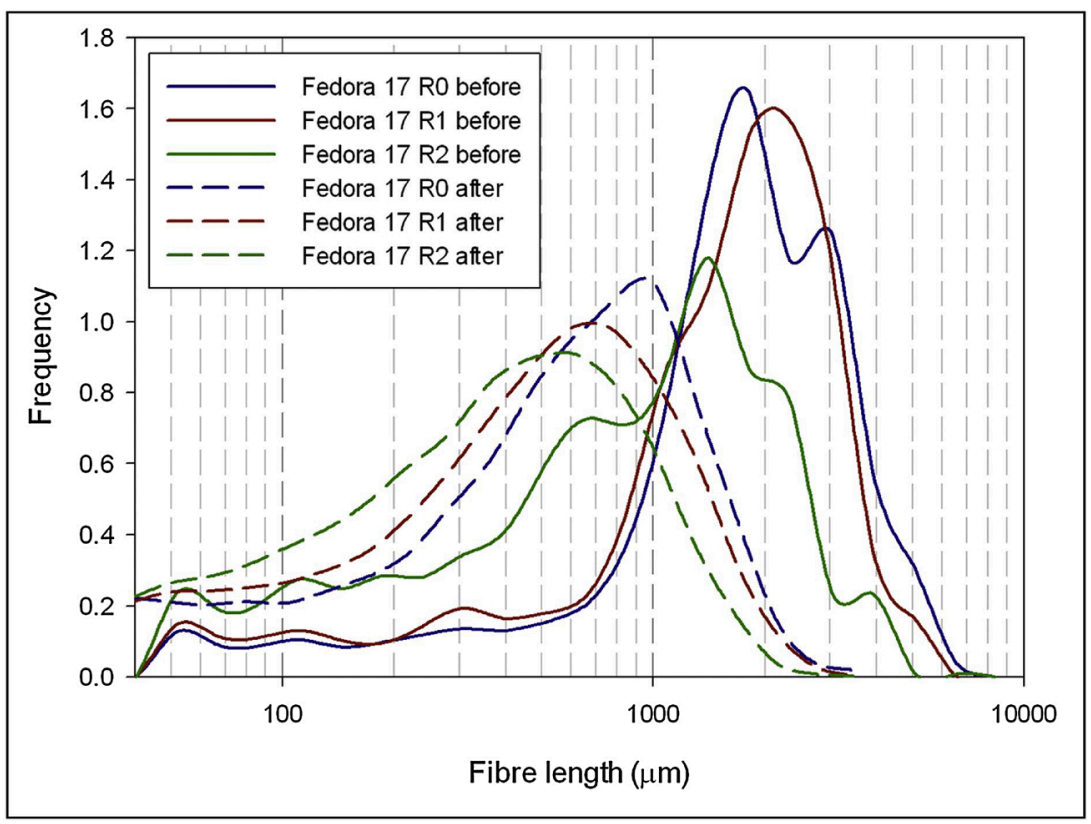

Fig. 9. Distribution of hemp fibre length before and after injection process for the Fedora 17 sample. 
This means that dew-retting can be successfully conducted in many different European regions. Different retting times will be necessary to achieve a suitable retting level, depending mostly on the level of rainfall during the dew-retting period. Dry territories such as Southeast France may be viewed as a completely unfavourable region, but if the stems are left for a suitably long period the dew retting process can be conducted up to its end. On the contrary, Northern Italy may be viewed as a highly favourable territory where dew-retting can be achieved in a short amount of time (less than 3 weeks in October).

Dew-retting, as performed at three different places subjected to different levels of solar radiation or rainfall, does not affect the level of the tensile properties measured. This demonstrates that well-performed dew-retting (i.e. neither under- or over-retted), neither decreased nor increased the mechanical potential of the fibres, and that by extension it did not degrade the main structural components, such as crystalline cellulose I, of the hemp fibres. However, this work also shows that the highest tensile values, adapted to the reinforcement of load-bearing composites, are maintained with the scutching and hackling process. On the other hand, the use of an all-fibre extraction device, suitable for multiple applications such as garment textiles for open-end spinning or for technical insulation wools, is not well suited to the production of load-bearing reinforcement fibres for high performance composites. However, such fibres could be used for injection-moulding composites as in that case, the composite properties are dependant not only on the fibre properties but also on the fibre arrangement within the composite.

If the mechanical properties are not improved by dew-retting at fibre and composite scale, the interest of this retting step could be doubtful. At the scale of manually-prepared UD composites, the interest is limited, but at industrial scale 1D to 3D reinforcement fabrics need to be manufactured and in those applications the textile manufacturing process does not accept coarse un-retted fibres. Consequently, a retting process such as dew-retting is required.

Field retting is classically performed in Northern and Western France, Belgium, and the Netherlands to facilitate the extraction and division of textile flax fibres. It can also be advantageously used to the same aim for hemp for load-bearing composite outputs in a wide range of European regions such as the ones studied in this work.

\section{Declaration of Competing Interest}

The authors declare that they have no known competing financial interests or personal relationships that could have appeared to influence the work reported in this paper.

\section{CRediT authorship contribution statement}

Samuel Réquilé: Conceptualization, Data curation, Formal analysis, Investigation, Visualization, Writing - original draft, Writing - review \& editing. Brahim Mazian: Data curation, Formal analysis, Investigation, Visualization, Writing - original draft, Writing - review \& editing. Marie Grégoire: Formal analysis, Investigation, Writing - review \& editing. Salvatore Musio: Formal analysis, Investigation, Writing - review \& editing. Maxime Gautreau: Formal analysis, Investigation, Writing review \& editing. Lucile Nuez: Formal analysis, Investigation, Writing review \& editing. Arnaud Day: Funding acquisition, Methodology, Writing - review \& editing. Pascal Thiébeau: Data curation, Methodology, Visualization, Writing - original draft, Writing - review \& editing. Florian Philippe: Data curation, Methodology. Brigitte Chabbert: Funding acquisition, Investigation, Methodology, Project administration, Writing - review \& editing. Anne Chamussy: Funding acquisition, Resources. Darshil U. Shah: Funding acquisition, Visualization, Writing - review \& editing. Johnny Beaugrand: Funding acquisition, Supervision, Writing - review \& editing. Vincent Placet: Funding acquisition, Project administration, Supervision, Writing - review \& editing. JeanCharles Benezet: Methodology, Supervision. Antoine le Duigou: Methodology, Supervision. Mahadev Bar: Formal analysis,
Investigation, Writing - review \& editing. Luc Malhautier: Methodology, Supervision, Writing - review \& editing. Emmanuel De Luycker: Methodology, Supervision. Stefano Amaducci: Funding acquisition, Project administration, Supervision, Writing - review \& editing. Christophe Baley: Project administration, Supervision, Writing - review \& editing. Anne Bergeret: Funding acquisition, Project administration, Supervision, Writing - review \& editing. Alain Bourmaud: Conceptualization, Funding acquisition, Project administration, Supervision, Visualization, Writing - original draft, Writing - review \& editing. Pierre Ouagne: Conceptualization, Project administration, Supervision, Funding acquisition, Visualization, Writing - review \& editing.

\section{Acknowledgements}

The authors are grateful to Oseo,Region Bretagne,CNRS, IMT (Institut Mines Telecom), Grand Est Region, Troyes Champagne Métropole as well as French Environment and Energy Management Agency (ADEME), in the framework of the Rightlab collaborative project, for funding this work. The authors thank Sylvie Recous, Bernard Kurek (UMR FARE) for their critical view of the manuscript.

Part of the research leading to some of the proposed results also received funding from the European Union Horizon 2020 Framework Programme for research and innovationunder grant agreement no. 744349: Project SSUCHY.

\section{References}

Acera Fernández, J., Le Moigne, N., Caro-Bretelle, A.S., El Hage, R., Le Duc, A., Lozachmeur, M., Bono, P., Bergeret, A., 2016. Role of flax cell wall components on the microstructure and transverse mechanical behaviour of flax fabrics reinforced epoxy biocomposites. Ind. Crops Prod. 85, 93-108. https://doi.org/10.1016/j. indcrop.2016.02.047.

Akin, D.E., Condon, B., Sohn, M., Foulk, J.A., Dodd, R.B., Rigsby, L.L., 2007. Optimization for enzyme-retting of flax with pectate lyase. Ind. Crops Prod. 25, 136-146. https://doi.org/10.1016/j.indcrop.2006.08.003.

Amaducci, S., Colauzzi, M., Bellocchi, G., Venturi, G., 2008. Modelling post-emergent hemp phenology (Cannabis sativa L.): theory and evaluation. Eur. J. Agron. 28, 90-102. https://doi.org/10.1016/j.eja.2007.05.006.

Bag, R., Beaugrand, J., Dole, P., Kurek, B., 2012. Treatment of chenevotte, a co-product of industrial hemp fiber, by water or hydrochloric acid: impact on polymer mobility in the lignified cell walls. J. Wood Sci. 58, 493-504. https://doi.org/10.1007/ s10086-012-1282-6.

Baley, C., Gomina, M., Breard, J., Bourmaud, A., Davies, P., 2020. Variability of mechanical properties of flax fibers for composite reinforcement. A review. Ind Crops Prod. 145, 111984. https://doi.org/10.1016/j.indcrop.2019.111984.

Ballif, J.L., Guerin, H., Muller, J.C., 1995. Eléments d'agronomie Champenoise. Connaissance Des Sols Et De Leur Fonctionnement. Quae Ed., 104 p.

Belda, M., Holtanova, E., Halenka, T., Kalvova, J., 2014. Climate classification revisited: from Köppen to Trewartha. Clim. Res. 59, 1-13. https://doi.org/10.3354/cr01204.

Belgacem, M., Gandini, A., 2005. The surface modification of cellulose fibres for use as reinforcing elements in composite materials. Compos. Interfaces 12, 41-75.

Bennett, S.J., Snell, R., Wright, D., 2006. Effect of variety, seed rate and time of cutting on fibre yield of dew-retted hemp. Ind. Crops Prod. 24, 79-86. https://doi.org/ 10.1016/j.indcrop.2006.03.007.

Bensadoun, F., Vallons, K.A.M., Lessard, L.B., Verpoest, I., Van Vuure, A.W., 2015. Fatigue behaviour assessment of flax-epoxy composites. Compos. Part A Appl. Sci. Manuf. 82, 253-266. https://doi.org/10.1016/j.compositesa.2015.11.003.

Bensadoun, F., Verpoest, I., Baets, J., Mussig, J., Graupner, N., Davies, P., Gomina, M., Kervoelen, A., Baley, C., 2017. Impregnated fibre bundle test for natural fibres used in composites. J. Reinf. Plast. and Comp. 36, 942-957.

Bleuze, L., Lashermes, G., Alavoine, G., Recous, S., Chabbert, B., 2018. Tracking the dynamics of hemp dew retting under controlled environmental conditions. Ind. Crops Prod. 123, 55-63. https://doi.org/10.1016/j.indcrop.2018.06.054.

Bourmaud, A., Baley, C., 2009. Rigidity analysis of polypropylene/vegetal fibre composites after recycling. Polym. Degrad. Stab. 94, 297-305. https://doi.org/ 10.1016/j.polymdegradstab.2008.12.010.

Bourmaud, A., Ausias, G., Lebrun, G., Tachon, M.-L., Baley, C., 2013a. Observation of the structure of a composite polypropylene/flax and damage mechanisms under stress. Ind. Crops Prod. 43, 225-236. https://doi.org/10.1016/j.indcrop.2012.07.030.

Bourmaud, A., Morvan, C., Bouali, A., Placet, V., Perré, P., Baley, C., 2013b. Relationships between micro-fibrillar angle, mechanical properties and biochemical composition of flax fibers. Ind. Crops Prod. 44, 343-351. https://doi.org/10.1016/j. indcrop.2012.11.031.

Bourmaud, A., Beaugrand, J., Shah, D., Placet, V., Baley, C., 2018. Towards the design of high-performance plant fibre composites. Prog. Mater. Sci. 97, 347-408. https://doi. org/10.1016/j.pmatsci.2018.05.005.

Brisson, N., Launay, M., Mary, B., Beaudoin, N., 2009. Conceptual Basis, Formalizations and Parameterization of the STICS Crop Model. Quae Ed., Versailles, 297 p. 
Chabbert, B., Padovani, J., Djemiel, C., Ossemond, J., Lemaitre, A., Yoshinaga, A., Hawkins, S., Grec, S., Beaugrand, J., Kurek, B., 2020. Multimodal assessment of flax dew retting and its functional impact on fibers and natural fiber composites. Ind. Crops Prod. 148 https://doi.org/10.1016/j.indcrop.2020.112255.

Coroller, G., Lefeuvre, A., Le Duigou, A., Bourmaud, A., Ausias, G., Gaudry, T., Baley, C., 2013. Effect of flax fibres individualisation on tensile failure of flax/epoxy unidirectional composite. Compos. Part A Appl. Sci. Manuf. 51, 62-70.

Crônier, D., Monties, B., Chabbert, B., 2005. Structure and chemical composition of bast fibers isolated from developing hemp stems. J. Agric. Food Chem. 53, 8279-8289.

Demske, D., Tarasov, P.E., Leipe, C., Kotlia, B.S., Joshi, L.M., Long, T., 2016. Record of vegetation, climate change, human impact and retting of hemp in Garhwal Himalaya (India) during the past 4600 years. Holocene 26 (10), 1661-1675. https://doi.org/ $10.1177 / 0959683616650267$.

Dickson, A.R., Even, D., Warnes, J.M., Fernyhough, A., 2014. The effect of reprocessing on the mechanical properties of polypropylene reinforced with wood pulp, flax or glass fibre. Compos. Part A Appl. Sci. Manuf. 61, 258-267. https://doi.org/10.1016/ j.compositesa.2014.03.010.

Djemiel, C., Grec, S., Hawkins, S., 2017. Characterisation of bacterial and fungal community dynamics by high-throughput sequencing (HTS) metabarcoding during flax dew-retting. Front. Microbiol. 8, 2052. https://doi.org/10.3389/ fmicb.2017.02052.

Duval, A., Bourmaud, A., Augier, L., Baley, C., 2011. Influence of the sampling area of the stem on the mechanical properties of hemp fibers. Mater. Lett. 65, 797-800. https:// doi.org/10.1016/j.matlet.2010.11.053.

Fuller, W.H., Norman, A.G., 1946. The retting of hemp III. Biochemical changes accompanying retting of hemp. Res. Bull. (Iowa Agriculture and Home Economics Experiment Station) 27 (344). Article at: http://lib.dr.iastate.edu/researchbullet in/vol27/iss344/1.

Garat, W., Corn, S., Le Moigne, N., Beaugrand, J., Bergeret, A., 2018. Analysis of the morphometric variations in natural fibres by automated laser scanning: towards an efficient and reliable assessment of the cross-sectional area. Compos. Part A Appl. Sci. Manuf. 108, 114-123. https://doi.org/10.1016/j.compositesa.2018.02.018.

George, J., Verpoest, J.I.I., 1999. Mechanical properties of flax fibre reinforced epoxy composites. Die Angew. Makromol. Chemie 272, 41-45. https://doi.org/10.1002/ (SICI)1522-9505(19991201)272:1<41::AID-APMC41>3.0.CO;2-X.

Goudenhooft, C., Bourmaud, A., Baley, C., 2019. Flax (Linumusitatissimum L.) Fibers for composite reinforcement: exploring the link between plant growth, cell walls development, and fiber properties. Front. Plant Sci. 10, 23. https://doi.org/10.3389/ fpls.2019.00411.

Graupner, N., Ziegmann, G., Wilde, F., Beckmann, F., Müssig, J., 2016. Procedural influences on compression and injection moulded cellulose fibre-reinforced polylactide (PLA) composites: Influence of fibre loading, fibre length, fibre orientation and voids. Compos. Part A Appl. Sci. Manuf. 81, 158-171.

Grégoire, M., Bar, M., De Luycker, E., Musio, S., Amaducci, S., Ouagne, P., 2020a. Study of the impact of scutching/hackling extraction on yields and mechanical properties of hemp fibres. Ind. Crops Prod. To be submitted.

Grégoire, M., Barthod-Malat, B., Labonne, L., Evon, P., De Luycker, E., Ouagne, P. 2020b. Investigation of the potential of hemp fibre straws harvested using a combine machine for the production of technical load-bearing textiles. Ind. Crops Prod. 145, 111988 https://doi.org/10.1016/j.indcrop.2019.111988.

Griffith, A., Taylor, G., 1921. The phenomena of rupture and flow in solids. VI. The phenomena of rupture and flow in solids. Phil. Trans. R. Soc. Lond. A 221, 163-198. https://doi.org/10.1098/rsta.1921.0006.

Haag, K., Padovani, J., Fita, S., Trouvé, J.P., Pineau, C., Hawkins, S., De Jong, H., Deyholos, M.K., Chabbert, B., Müssig, J., Beaugrand, J., 2017. Influence of flax fibre variety and year-to-year variability on composite properties. Ind. Crops Prod. 98, 1-9. https://doi.org/10.1016/j.indcrop.2016.12.028.

Hanninen, T., Michud, A., Hughes, M., 2011. Kink bands in bast fibres and their effects on mechanical properties. Plast. Rubber Compos. 40 (6-7), 307-310.

Hessler, L.E., 1945. Chemical and strength differences in dew-retted hemp fiber. J. Amer Soc. Agron. 37-2, 146-155.

Hessler, L.E., 1946. Chemical removal of encrustants from dew-retted hemp fiber. J. Agric. Res. 78 (5-6), 153-159.

Jankauskienè, Z., Butkutè, B., Gruzdevienè, E., Cesevičienè, J., Fernando, A.L., 2015. Chemical composition and physical properties of dew- and water-retted hemp fibers. Ind. Crops Prod. 75, 206-211. https://doi.org/10.1016/j.indcrop.2015.06.044.

John, M.J., Anandjiwala, R.D., 2008. Recent developments in chemical modification and characterisation of natural fiber-reinforced composites. Polym. Compos. 29, 187-207. https://doi.org/10.1002/pc.20461.

Kabir, M.M., Wang, H., Lau, K.T., Cardona, F., 2012. Chemical treatments on plant-based natural fibre reinforced polymer composites: an overview. Compos. Part B Eng. 43, 2883-2892. https://doi.org/10.1016/j.compositesb.2012.04.053.

Kalia, S., Kaith, B., Kaur, I., 2009. Pretreatments of natural fibers and their application as reinforcing material in polymer composites-a review. Polym. Eng. Sci. 49, 1253-1272.

Law, A.D., McNees, C.R., Moe, L.A., 2020. The microbiology of hemp retting in a controlled environment: steering the hemp microbiome towards more consistent fiber production. Agronomy 10-14, 492. https://doi.org/10.3390/ agronomy10040492.

Le Moigne, N., Otazaghine, B., Corn, S., Angellier-Coussy, H., Bergeret, A., 2018 Surfaces and interfaces in natural fibre reinforced composites. In: Springer (Ed.) Springer Briefs in Molecular Science. Springer International Publishing, Cham. https://doi.org/10.1007/978-3-319-71410-3.
Liu, M., Fernando, D., Daniel, G., Madsen, B., Meyer, A.S., Ale, M.T., Thygesen, A., 2015.

Effect of harvest time and field retting duration on the chemical composition, morphology and mechanical properties of hemp fibers. Ind. Crops Prod. 69, 29-39. https://doi.org/10.1016/j.indcrop.2015.02.010.

Liu, M., Silva, D.A.S., Fernando, D., Meyer, A.S., Madsen, B., Daniel, G., Thygesen, A. 2016. Controlled retting of hemp fibres: effect of hydrothermal pre-treatment and enzymatic retting on the mechanical properties of unidirectional hemp/epoxy composites. Compos. Part A Appl. Sci. Manuf. 88, 253-262. https://doi.org/ 10.1016/j.compositesa.2016.06.003.

Liu, M., Thygesen, A., Summerscales, J., Meyer, A.S., 2017. Targeted pre-treatment of hemp bast fibres for optimal performance in biocomposite materials: a review. Ind. Crops Prod. 108, 660-683. https://doi.org/10.1016/j.indcrop.2017.07.027.

Marrot, L., Lefeuvre, A., Pontoire, B., Bourmaud, A., Baley, C., 2013. Analysis of the hemp fiber mechanical properties and their scattering (Fedora 17). Ind. Crops Prod. 51, 317-327. https://doi.org/10.1016/j.indcrop.2013.09.026.

Martin, N., Mouret, N., Davies, P., Baley, C., 2013. Influence of the degree of retting of flax fibers on the tensile properties of single fibers and short fiber/polypropylene composites. Ind. Crops Prod. 49, 755-767. https://doi.org/10.1016/j. indcrop.2013.06.012.

Mary, B., Beaudoin, N., Justes, E., Machet, J.M., 1999. Accumulation of nitrogen mineralization and leaching in fallow soil using a simple model. Eur. J. Soil Sci. 50 (4), 549-566. https://doi.org/10.1046/j.1365-2389.1999.00264.x.

Masto, A.Del, Trivaudey, F., Guicheret-Retel, V., Placet, V., Boubakar, L., 2019. Investigation of the possible origins of the differences in mechanical properties of hemp and flax fibres: a numerical study based on sensitivity analysis. Compos. Part A Appl. Sci. Manuf. 124, 105488 https://doi.org/10.1016/j. compositesa.2019.105488.

Mazian, B., Bergeret, A., Benezet, J.-C., Malhautier, L., 2018. Influence of field retting duration on the biochemical, microstructural, thermal and mechanical properties of hemp fibres harvested at the beginning of flowering. Ind. Crops Prod. 116, 170-181. https://doi.org/10.1016/j.indcrop.2018.02.062.

Musio, S., Müssig, J., Amaducci, S., 2018. Optimizing hemp fiber production for high performance composite applications. Front. Plant Sci. 9, 1702. https://doi.org/ 10.3389/fpls.2018.01702.

Müssig, J., Haag, K., Musio, S., Bjelková, M., Albrecht, K., Uhrlaub, B., Wang, S., Wieland, H.J., Amaducci, S., 2020. Biobased 'Mid-performance' composites using losses from the hackling process of long hemp - a feasibility study as part of the development of a biorefinery concept. Ind. Crops Prod. 145 https://doi.org/ 10.1016/j.indcrop.2019.111938.

Park, S., Baker, J.O., Himmel, M.E., Parilla, P.A.D.K., 2010. Cellulose crystallinity index: measurement techniques and their impact on interpreting cellulase performance. Biotechnol. Biofuels 3, 10. https://doi.org/10.1186/1754-6834-3-10.

Placet, V., 2009. Characterisation of the thermo-mechanical behaviour of hemp fibres intended for the manufacturing of high performance composites. Compos. Part A Appl. Sci. Manuf. - Spec. Issue 15th French Natl. Conf. Compos. - JNC15 40, 1111-1118. https://doi.org/10.1016/j.compositesa.2009.04.031.

Placet, V., Trivaudey, F., Cisse, O., Gucheret-Retel, V., Boubakar, M.L., 2012. Diameter dependence of the apparent tensile modulus of hemp fibres: a morphological, structural or ultrastructural effect? Compos. Part A Appl. Sci. Manuf. 43, 275-287.

Placet, V., Day, A., Beaugrand, J., 2017. The influence of unintended field retting on the physicochemical and mechanical properties of industrial hemp bast fibres. J. Mater. Sci. 52, 5759-5777. https://doi.org/10.1007/s10853-017-0811-5.

Réquilé, S., Duigou, A.Le, Bourmaud, A., Baley, C., 2018a. Peeling experiments for hemp retting characterisation targeting biocomposites. Ind. Crops Prod. 123, 573-580. https://doi.org/10.1016/j.indcrop.2018.07.012.

Réquilé, S., Goudenhooft, C., Bourmaud, A., Le Duigou, A., Baley, C., 2018b. Exploring the link between flexural behaviour of hemp and flax stems and fibre stiffness. Ind. Crops Prod. 113, 179-186. https://doi.org/10.1016/j.indcrop.2018.01.035.

Ribeiro, A., Pochart, P., Day, A., Mennuni, S., Bono, P., Baret, J.L., Spadoni, J.L., Mangin, I., 2015. Microbial diversity observed during hemp retting. Appl. Microbiol. Biotechnol. 99, 4471-4484. https://doi.org/10.1007/s00253-014-6356-5.

Segal, L., Creely, J.J., Martin Jr., A.E., Conrad, C.M., 1962. An empirical method for estimating the degree of crystallinity of native cellulose using the x-ray diffractometer. Tex. Res. J. 29, 786-794. https://doi.org/10.1177/ 004051755902901003.

Tanguy, M., Bourmaud, A., Beaugrand, J., Gaudry, T., Baley, C., 2018. Polypropylene reinforcement with flax or jute fibre: influence of microstructure and constituents properties on the performance of composite. Compos. Part B Eng. 139, 64-74. https://doi.org/10.1016/j.compositesb.2017.11.061.

Thiebeau, P., Recous, S., 2017. Crop residues decomposition dynamics in farms practising conservation agriculture in the Grand Est region, France. Cah. Agric. 26, 65001 doi:101051/cagri/2017050.

Tuck, A., 2018. Medieval hemp retting? Excavations at Bridge Lane House, Bawtry, Doncaster. Yorshire Archeol. J. 90-1, 200-202. https://doi.org/10.1080/ 00844276.2018 .1483134$.

Van Der Werf, H.M.G., Brouwer, K., Wijlhuizen, M., Withagen, J.C.M., 1995. The effect of temperature on leaf appearance and canopy establishment in fibre hemp (Cannabis sativa L.). Ann. appl. Bot. 126, 551-561.

Vandepitte, K., Vasile, S., Vermeire, S., Vanderhoeven, M., Van Der Borght, W., Latre, J. de Raeve, A., Troch, V., 2020. Hemp (Cannabis sativa L.) for high-value textile applications: the effective long fiber yield and quality of different hemp varieties, processed using industrial flax equipment. Ind. Crops Prod. 158, 112969. 